\title{
Anionic activation of the Wittig reaction using a solid-liquid phase transfer: examination of the medium-, temperature-, base- and phase-transfer catalyst effects
}

\author{
Younes Moussaoui, Khemais Saïd, and Ridha Ben Salem* \\ * Physical Organic Chemistry Laboratory, Science Faculty of Sfax, 3018, Sfax, Tunisia. \\ E-mail: Ridha.BenSalem@voila.fr
}

\begin{abstract}
Potassium carbonate is a remarkable base in the Wittig reaction. It promotes the formation of ethylenic compounds in excellent yields, by a biphasic solid-liquid process. There is modest reactivity in the presence of hydroxides. The $Z$-isomer is the major product in aprotic media whereas the $E$-isomer is promoted in protic media. The addition of phase-transfer agents accelerates the reaction. However sodium hydroxide on alumina can be used as the basic system for the Wittig reaction.
\end{abstract}

Keywords: Wittig reaction, anionic activation, phase transfer catalysis .

\section{Introduction}

The Wittig reaction has been from its infancy a very important method for the formation of carbon-carbon double bonds. ${ }^{1,2}$ It is seen as the key step for the synthesis of many natural products. $^{3}$ The basic reagent in the Wittig process is prepared via deprotonation of the corresponding phosphonium salt obtained by quaternization of a phosphine with a halo compound. ${ }^{4}$ The synthesis of phosphonium salts often requires harsh conditions. It is usually necessary to heat the phosphine-halo compound mixture under reflux for several hours, even days. A better methodology would obviously be welcome. ${ }^{5}$

The mechanism of the Wittig reaction has been abundantly studied. The betaine $\underline{\mathbf{a}}$ was formerly considered to be the main intermediate. ${ }^{6}$ In 1973, Vedejs and Snoble ${ }^{7}$ detected only oxaphosphetane $\underline{\mathbf{b}}$ by NMR spectroscopy during the course of the reaction. 


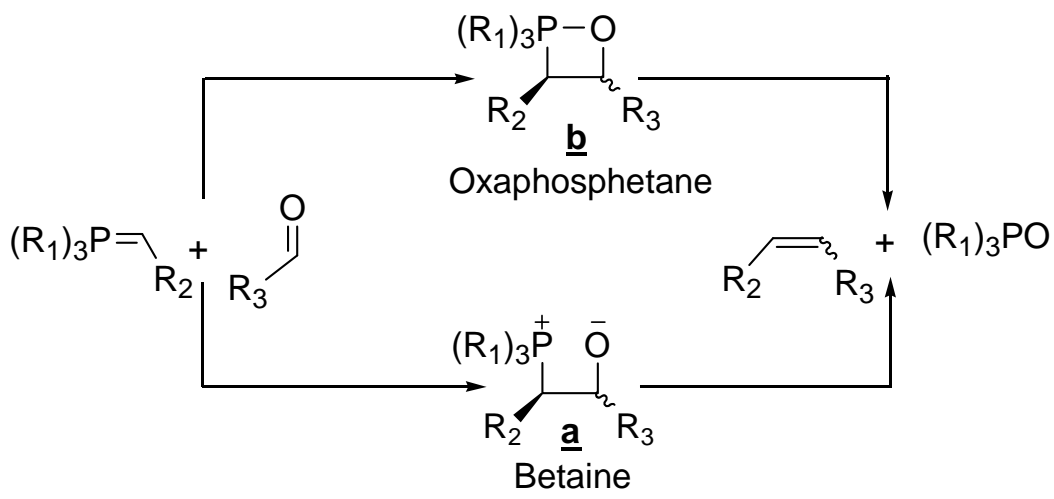

Both intermediates are unstable and decompose into alkene and phosphine oxide. The main advantage of the Wittig reaction is its stereoselectivity. ${ }^{8}$ The stereochemistry depends on several parameters: the structure of the phosphonium salt, ${ }^{9-15}$ the presence of metal cations, ${ }^{1,16,17}$ and the experimental conditions. ${ }^{18-21}$ From this point of view, phase-transfer catalysis in the BaylissHillman, aldolization, ketoaldolization reactions, ${ }^{22}$ and in the synthesis of cyclopropanes, ${ }^{23}$ often requires phase-transfer agents such as quaternary ammonium salts or crown-ethers. Although Wittig reactions in liquid-solid biphasic conditions do not necessarily require the presence of such compounds, ${ }^{24,25}$ the latter do, however, permit one to lower, or even impede, the rate of secondary reactions, e.g., Knœvenage ${ }^{24}$ or Cannizzaro reactions. ${ }^{26}$ We have shown that the use of hydroxides and carbonates in solid-liquid phase-transfer conditions in slightly hydrated organic mixtures ${ }^{27,28}$ or formamide ${ }^{29}$ permits one to obtain alkenes from aldehydes with very good yield and selectivity ratios. However, in the Wittig olefination reactions of Garner's aldehyde $^{30}$ with non-stabilized ylides, the $(E)$ alkenes could be produced as a major product by simply quenching the reaction with a large excess of methanol at $-78^{\circ} \mathrm{C}$. ${ }^{21}$ Without addition of methanol, the usual selectivity for the $(Z)$ alkenes was obtained in ratio of $94: 6{ }^{21}$

We report in this Paper a thorough study of several effects (solvent, base, temperature, addition of phase-transfer catalysts) in the Wittig reaction between propyltriphenylphosphonium bromide, pentyltriphenylphosphonium bromide, and various carbonyl compounds. In addition, a reaction mechanism is proposed to rationalize the results.

\section{Results and Discussion}

\section{Solvent effect}

According to Table 1, the yield depends on the solvent. A higher dielectric constant is associated with an improved yield. Such solvents enhance the base strength through the dissociation of the cation-anion link of the basis, the activation of the basic entity opposite the acidic hydrogen of the phosphonium salt and facilitates desorption of the formed ylide.

In aqueous media the rate is lowered and, even more in water-hexane mixtures. These results are due to the low solubility of the aldehyde in water and strong stability of reaction 
intermediates (betaine and oxaphosphetane) through hydrogen bonds. The ylide solvation is a hydrolysis reaction leading to the formation of phosphine oxide and benzene as shown in the mechanism of the Wittig reaction between benzaldehyde and propyltriphenylphosphonium bromide in aqueous medium in the presence of potassium carbonate (Scheme 1).

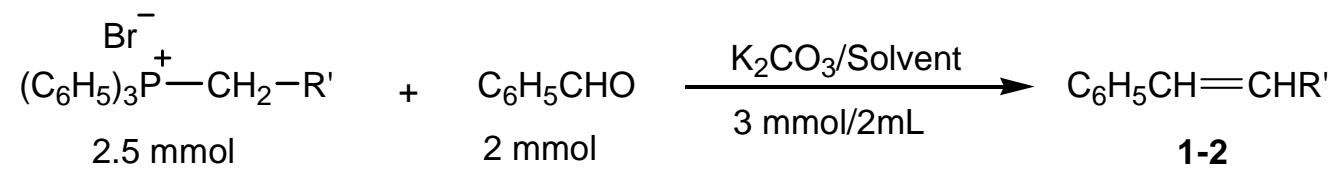

Table 1. Influence of the solvent on Wittig reactions of benzaldehyde and various phosphonium salts

\begin{tabular}{|c|c|c|c|c|c|}
\hline Solvent / Time & $\varepsilon\left(25^{\circ} \mathrm{C}\right)$ & $\mathrm{T}\left({ }^{\circ} \mathrm{C}\right)$ & $\mathrm{R}^{\prime}$ & Product & Yield / \% \\
\hline $\mathrm{H}_{2} \mathrm{O}$ & \multirow{2}{*}{87} & \multirow{2}{*}{100} & $\mathrm{C}_{2} \mathrm{H}_{5}$ & 1 & 70 \\
\hline $24 \mathrm{~h}$ & & & $\mathrm{C}_{4} \mathrm{H}_{9}$ & 2 & 72 \\
\hline $\mathrm{CH}_{3} \mathrm{OH}(* *)$ & \multirow{2}{*}{32.6} & \multirow{2}{*}{65} & $\mathrm{C}_{2} \mathrm{H}_{5}$ & 1 & 84 \\
\hline $2 \mathrm{~h}$ & & & $\mathrm{C}_{4} \mathrm{H}_{9}$ & 2 & 86 \\
\hline $\mathrm{C}_{2} \mathrm{H}_{5} \mathrm{OH}$ & \multirow{2}{*}{24.3} & \multirow{2}{*}{65} & $\mathrm{C}_{2} \mathrm{H}_{5}$ & 1 & 60 \\
\hline $2 \mathrm{~h}$ & & & $\mathrm{C}_{4} \mathrm{H}_{9}$ & 2 & 64 \\
\hline $\mathrm{C}_{3} \mathrm{H}_{7} \mathrm{OH}$ & \multirow{2}{*}{20.1} & \multirow{2}{*}{65} & $\mathrm{C}_{2} \mathrm{H}_{5}$ & 1 & 58 \\
\hline $2 \mathrm{~h}$ & & & $\mathrm{C}_{4} \mathrm{H}_{9}$ & 2 & 61 \\
\hline $\mathrm{C}_{4} \mathrm{H}_{9} \mathrm{OH}$ & \multirow{2}{*}{17.1} & \multirow{2}{*}{65} & $\mathrm{C}_{2} \mathrm{H}_{5}$ & 1 & 55 \\
\hline $2 \mathrm{~h}$ & & & $\mathrm{C}_{4} \mathrm{H}_{9}$ & 2 & 55 \\
\hline Acetonitrile (*) & \multirow{2}{*}{37.5} & \multirow{2}{*}{80} & $\mathrm{C}_{2} \mathrm{H}_{5}$ & 1 & 66 \\
\hline $2 \mathrm{~h}$ & & & $\mathrm{C}_{4} \mathrm{H}_{9}$ & 2 & 68 \\
\hline Hexane $(*)$ & \multirow{2}{*}{1.9} & \multirow{2}{*}{65} & $\mathrm{C}_{2} \mathrm{H}_{5}$ & 1 & 24 \\
\hline $2 \mathrm{~h}$ & & & $\mathrm{C}_{4} \mathrm{H}_{9}$ & 2 & 25 \\
\hline Dichloromethane (*) & \multirow{2}{*}{9.08} & \multirow{2}{*}{40} & $\mathrm{C}_{2} \mathrm{H}_{5}$ & 1 & 20 \\
\hline $2 \mathrm{~h}$ & & & $\mathrm{C}_{4} \mathrm{H}_{9}$ & 2 & 20 \\
\hline 1,4-Dioxane & \multirow{4}{*}{2.21} & \multirow{2}{*}{95} & $\mathrm{C}_{2} \mathrm{H}_{5}$ & 1 & 72 \\
\hline $2 \mathrm{~h}$ & & & $\mathrm{C}_{4} \mathrm{H}_{9}$ & 2 & 74 \\
\hline Water: hexane $=1: 1$ & & \multirow{2}{*}{65} & $\mathrm{C}_{2} \mathrm{H}_{5}$ & 1 & 55 \\
\hline $48 \mathrm{~h}$ & & & $\mathrm{C}_{4} \mathrm{H}_{9}$ & 2 & 55 \\
\hline
\end{tabular}

* Water $(2 \mathrm{mmol})$ is added. ** $2 \mathrm{~mL}$ methanol with $0.18 \mathrm{mmol}$ water. 


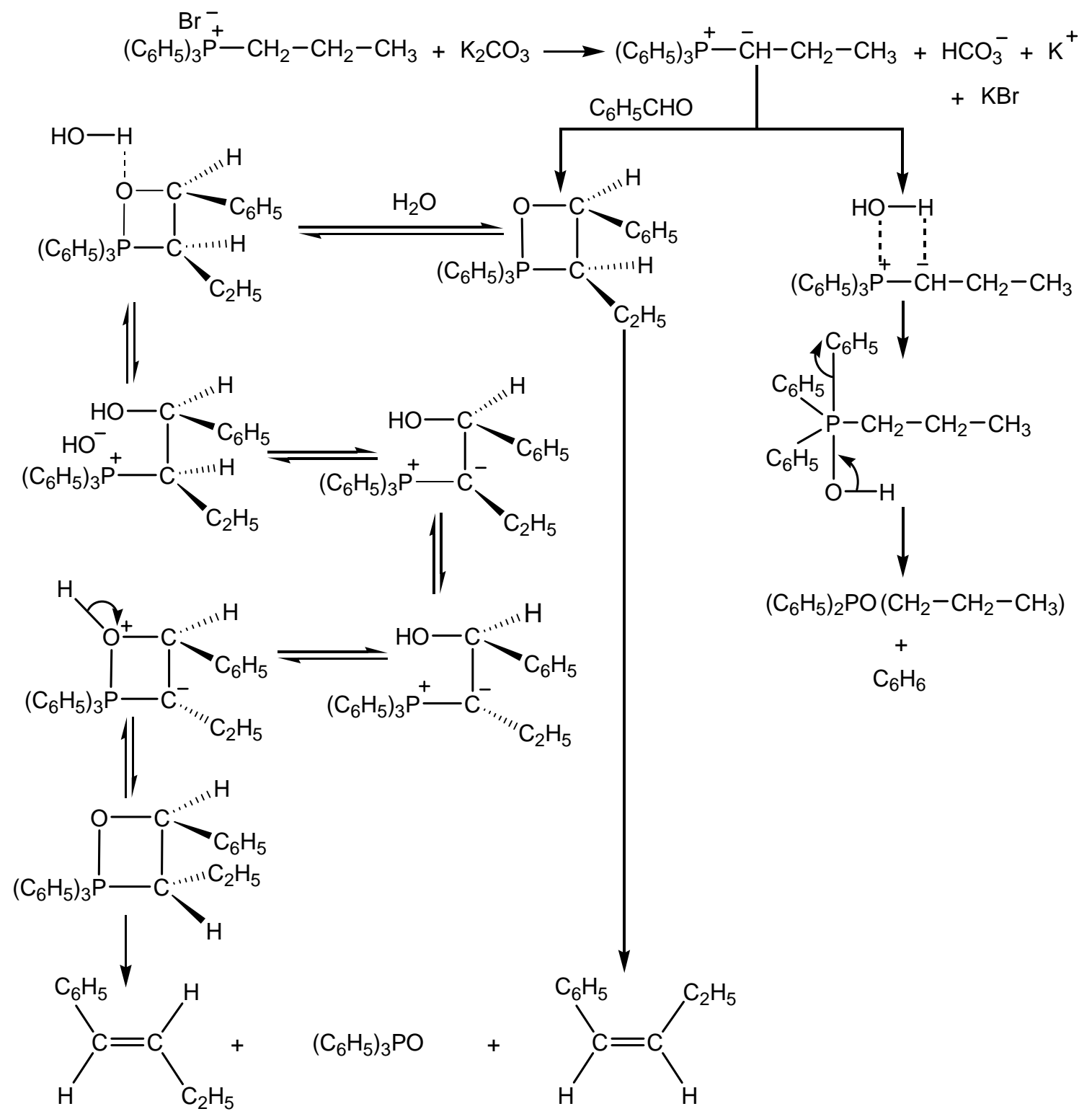

Scheme 1. Mechanism of the Wittig reaction between benzaldehyde and propyltriphenylphosphonium bromide in aqueous medium in the presence of potassium carbonate.

Table 2 reports that the addition of water to methanol decreases the alkene yield whereas the reactivity is increased in dioxane-water mixtures: a maximum is reached for water contents of 1-1.5 eq, the yield being decreased beyond. The "free" water content in methanol lowers the alkene yield owing to partial hydrolysis of the ylide into propyldiphenylphosphine oxide and benzene. Scheme 2 details the mechanism of the Wittig reaction between benzaldehyde and propyltriphenylphosphonium bromide in aprotic media. 
Table 2. Effect of water and methanol on Wittig reactions of benzaldehyde and various phosphonium salts

\begin{tabular}{|c|c|c|c|}
\hline Solvent & Additive & $\mathrm{R}^{\prime}$ & Yield / \% \\
\hline \multirow{22}{*}{ Dioxane } & \multirow{2}{*}{ 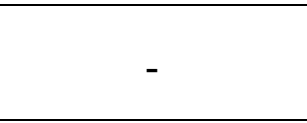 } & $\mathrm{C}_{2} \mathrm{H}_{5}$ & 72 \\
\hline & & $\mathrm{C}_{4} \mathrm{H}_{9}$ & 74 \\
\hline & \multirow{2}{*}{ 1mmol methanol } & $\mathrm{C}_{2} \mathrm{H}_{5}$ & 17 \\
\hline & & $\mathrm{C}_{4} \mathrm{H}_{9}$ & 18 \\
\hline & \multirow{2}{*}{$2 \mathrm{mmol}$ methanol } & $\overline{\mathrm{C}_{2} \mathrm{H}_{5}}$ & 33 \\
\hline & & $\mathrm{C}_{4} \mathrm{H}_{9}$ & 33 \\
\hline & \multirow{2}{*}{$3 \mathrm{mmol}$ methanol } & $\mathrm{C}_{2} \mathrm{H}_{5}$ & 35 \\
\hline & & $\mathrm{C}_{4} \mathrm{H}_{9}$ & 36 \\
\hline & \multirow{2}{*}{ 4mmol methanol } & $\mathrm{C}_{2} \mathrm{H}_{5}$ & 42 \\
\hline & & $\mathrm{C}_{4} \mathrm{H}_{9}$ & 44 \\
\hline & \multirow{2}{*}{$5 \mathrm{mmol}$ methanol } & $\mathrm{C}_{2} \mathrm{H}_{5}$ & 63 \\
\hline & & $\mathrm{C}_{4} \mathrm{H}_{9}$ & 65 \\
\hline & \multirow{2}{*}{$1 \mathrm{mmol}$ water } & $\mathrm{C}_{2} \mathrm{H}_{5}$ & 77 \\
\hline & & $\mathrm{C}_{4} \mathrm{H}_{9}$ & 78 \\
\hline & \multirow{2}{*}{$2 \mathrm{mmol}$ water } & $\mathrm{C}_{2} \mathrm{H}_{5}$ & 95 \\
\hline & & $\mathrm{C}_{4} \mathrm{H}_{9}$ & 97 \\
\hline & \multirow{2}{*}{$3 \mathrm{mmol}$ water } & $\mathrm{C}_{2} \mathrm{H}_{5}$ & 94 \\
\hline & & $\mathrm{C}_{4} \mathrm{H}_{9}$ & 94 \\
\hline & \multirow{2}{*}{$4 \mathrm{mmol}$ water } & $\mathrm{C}_{2} \mathrm{H}_{5}$ & 67 \\
\hline & & $\mathrm{C}_{4} \mathrm{H}_{9}$ & 67 \\
\hline & \multirow{2}{*}{$6 \mathrm{mmol}$ water } & $\mathrm{C}_{2} \mathrm{H}_{5}$ & 56 \\
\hline & & $\mathrm{C}_{4} \mathrm{H}_{9}$ & 56 \\
\hline \multirow{10}{*}{ Methanol (**) } & \multirow[b]{2}{*}{-} & $\mathrm{C}_{2} \mathrm{H}_{5}$ & 84 \\
\hline & & $\mathrm{C}_{4} \mathrm{H}_{9}$ & 86 \\
\hline & \multirow{2}{*}{$1 \mathrm{mmol}$ water } & $\mathrm{C}_{2} \mathrm{H}_{5}$ & 58 \\
\hline & & $\mathrm{C}_{4} \mathrm{H}_{9}$ & 59 \\
\hline & \multirow{2}{*}{$2 \mathrm{mmol}$ water } & $\mathrm{C}_{2} \mathrm{H}_{5}$ & 52 \\
\hline & & $\mathrm{C}_{4} \mathrm{H}_{9}$ & 55 \\
\hline & \multirow{2}{*}{$3 \mathrm{mmol}$ water } & $\mathrm{C}_{2} \mathrm{H}_{5}$ & 44 \\
\hline & & $\mathrm{C}_{4} \mathrm{H}_{9}$ & 48 \\
\hline & \multirow{2}{*}{$4 \mathrm{mmol}$ water } & $\mathrm{C}_{2} \mathrm{H}_{5}$ & 40 \\
\hline & & $\mathrm{C}_{4} \mathrm{H}_{9}$ & 40 \\
\hline
\end{tabular}

* Methanol $\left(65^{\circ} \mathrm{C}\right)$, dioxane $\left(95^{\circ} \mathrm{C}\right)$, time $3 \mathrm{~h}$.

** Methanol, $2 \mathrm{~mL}$, with $0.18 \mathrm{mmol}$ water. 


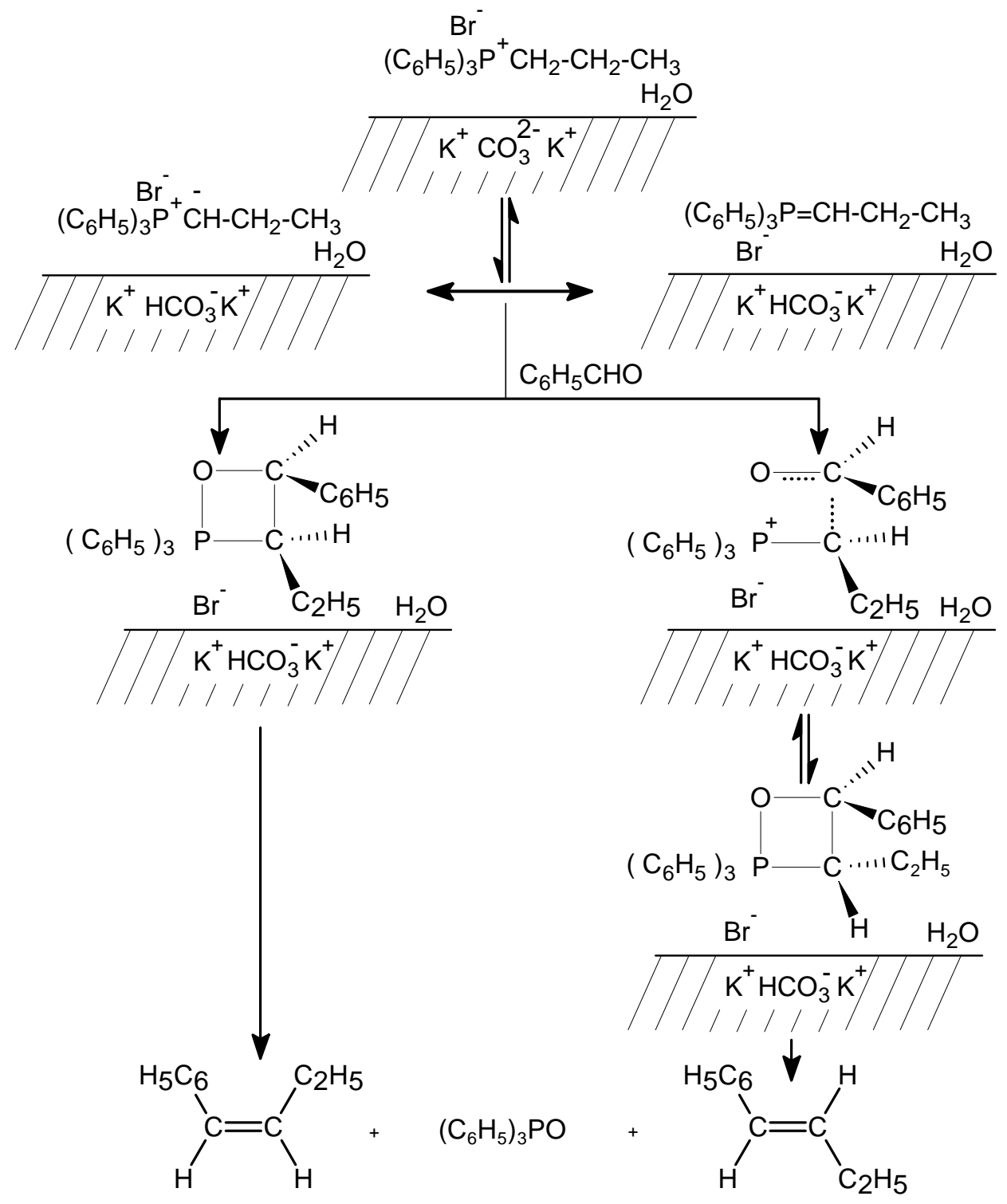

Scheme 2. Mechanism of the Wittig reaction between benzaldehyde and propyltriphenylphosphonium bromide in 1,4-dioxane in the presence of potassium carbonate (solid-liquid phase-transfer process).

\section{Base effect}

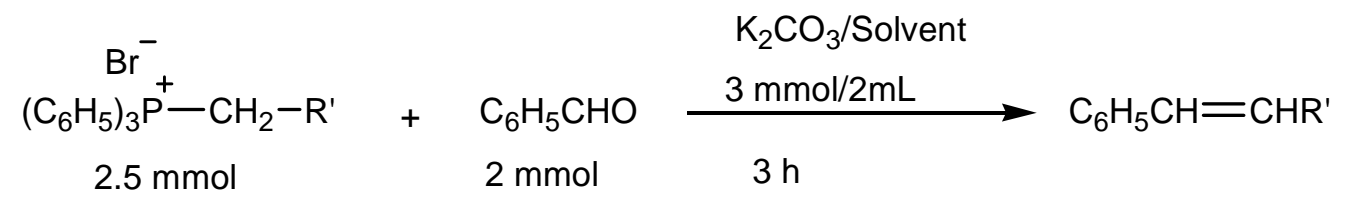

The results of Table 3 show a modest reactivity in the presence of hydroxides. With carbonates such as $\mathrm{K}_{2} \mathrm{CO}_{3}$ and $\mathrm{Cs}_{2} \mathrm{CO}_{3}$ the yields are better (80\% in methanol and nearly quantitative in 
dioxane). The modest reactivity could be due to the formation of secondary products from the Cannizzaro reaction, or hydrolysis of the ylide in the presence of $\mathrm{NaOH}$ or $\mathrm{KOH}$. This is no more the case when carbonates are present. The results are in agreement with those of Le Bigot. ${ }^{31}$ He proposed that secondary reactions are inhibited in the presence of carbonate ions. The formation of water when hydroxides are used favors solvation of the ylide in the first step of the Wittig process. In addition, the yield of alkene increases with the size of the cation, in relation to the cohesion energy density of the carbonates.

Table 3. Base effect on the Wittig reaction between benzaldehyde and propyltriphenylphosphonium bromide

\begin{tabular}{cccc}
\hline & Reticular energy & \multicolumn{2}{c}{ Yield / \% } \\
\cline { 3 - 4 } Base & Kj.mol & Anhydrous dioxane (*) & Methanol (**) \\
\cline { 3 - 4 } $\mathrm{Cs}_{2} \mathrm{CO}_{3}$ & 1921 & 97 & 80 \\
$\mathrm{~K}_{2} \mathrm{CO}_{3}$ & 2084 & 95 & 79 \\
$\mathrm{Na}_{2} \mathrm{CO}_{3}$ & 2301 & 13 & 15 \\
$\mathrm{Li}_{2} \mathrm{CO}_{3}$ & - & 0 & 0 \\
$\mathrm{KOH}$ & - & 42 & 35 \\
$\mathrm{NaOH}$ & 824 & 40 & 32 \\
\hline
\end{tabular}

* Water, $2 \mathrm{mmol}$, is added. ** Methanol $(2 \mathrm{~mL})$ with $0.18 \mathrm{mmol}$ water.

\section{Temperature effect}

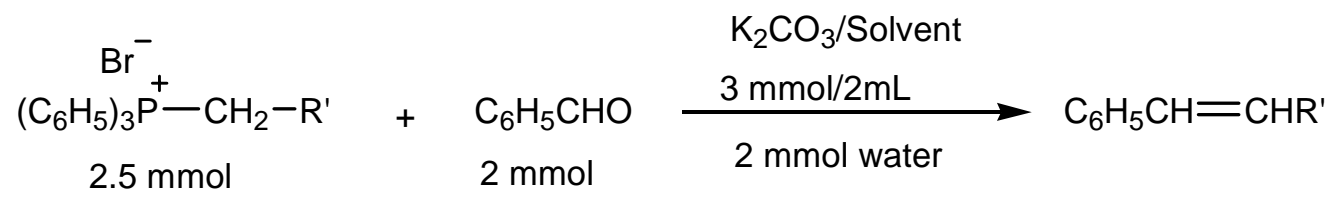

\begin{tabular}{cccc}
\hline Solvent & Time $(\mathrm{h})$ & $\mathrm{T}\left({ }^{\circ} \mathrm{C}\right)$ & Yield $/ \%$ \\
$\mathrm{CH}_{2} \mathrm{Cl}_{2}$ & 3 & 40 & 20 \\
$\mathrm{CH}_{2} \mathrm{Cl}_{2}$ & 18 & 40 & 92 \\
Dioxane & 3 & 95 & 95 \\
\hline
\end{tabular}

The reaction proceeds with quantitative yields in dioxane $\left(95^{\circ} \mathrm{C}, 3 \mathrm{~h}\right)$. Under otherwise identical conditions the yields are lowered in dichloromethane. Prolonged reaction times (18h) lead to $92 \%$ yield. The result is probably related to temperature and not solely traceable to the solvent used. To assess the hypothesis we carried out the Wittig reaction between benzaldehyde and propyltriphenylphosphonium bromide in dioxane in the presence of potassium carbonate at different temperatures (Table 4). A higher temperature results in higher alkene yields. This may be explained by enhanced basicity of the carbonate with increasing temperature which weakens 
bonds between the potassium cation and carbonate anions, thereby reducing the cohesion energy density.

Table 4. Temperature effect on the Wittig reaction between benzaldehyde and propyltriphenylphosphonium bromide

\begin{tabular}{ccc}
\hline $\mathrm{T}{ }^{\circ} \mathrm{C}$ & Time (h) & Yield $/ \%$ \\
20 & 4 & 19 \\
40 & 4 & 32 \\
60 & 4 & 52 \\
70 & 4 & 65 \\
95 & 3 & 95 \\
\hline
\end{tabular}

\section{Reactivity of the carbonyl bond}

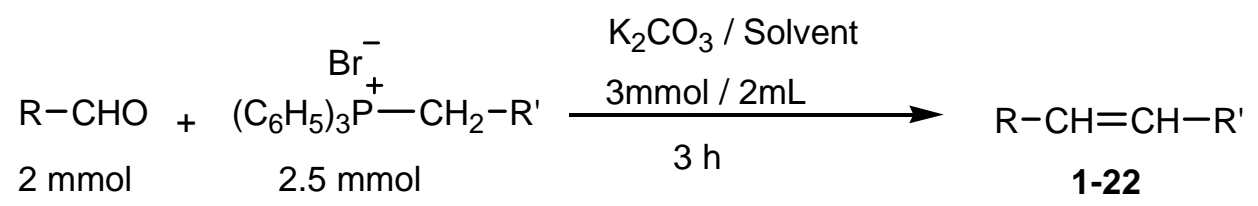

\section{Aromatic aldehydes}

Placing electron-donor substituents on the aromatic ring bearing the carbonyl group leads to a slowing down of the condensation between the ylide and the aldehyde in any medium, protic or aprotic, and therefore a decrease of the alkene yield. In fact, a group featuring either inductive $(+\mathrm{I})$ or mesomeric $(+\mathrm{M})$ effects on the aromatic ring of the carbonyl compound increases the charge density of the carbon atom of the $\mathrm{CHO}$ group, weakening thereby its electrophilicity toward the ylide. It should also be observed that $(E)$-alkenes are promoted in protic media compared to the major formation of $(Z)$-alkenes in aprotic media.

\section{Aliphatic aldehydes}

According to Table 6, the yields are higher when potassium carbonate is used in place of sodium hydroxide. The reactions proceed cleanly without formation of aldol products. The inhibition of the aldol reaction in the presence of potassium carbonate is ascribed to the absence of acid-base interactions between the enolizable hydrogen and the carbonate anion. In such conditions, the anion is not active enough to react. The solid state of $\mathrm{K}_{2} \mathrm{CO}_{3}$ promotes formation of an anion which could subsequently induce the formation of the ylide and not abstraction of the labile hydrogen at the interface. The formation of alkenes from aldehydes proceeds, therefore, according to a solid-liquid phase transfer. In addition, the reactivity decreases with increasing chain length of the aldehyde. The result can be explained by the donating effect of the alkyl group placed on the carbonyl bond, increasing thereby, the electronic density on the carbon of the carbonyl which is detrimental for the attack of the ylide. 
Table 5. Condensation of aldehydes diversely substituted with propyltriphenylphosphonium and pentyltriphenylphosphonium bromide

\begin{tabular}{|c|c|c|c|c|c|c|}
\hline \multirow[b]{2}{*}{$\mathrm{R}$} & \multirow[b]{2}{*}{$\mathrm{R}^{\prime}$} & \multirow[b]{2}{*}{ Product } & \multicolumn{2}{|c|}{ Dioxane1-4 $(*)$} & \multicolumn{2}{|c|}{ Methanol $(* *)$} \\
\hline & & & Yield, \% & $E / Z$ & Yield, \% & $E / Z$ \\
\hline \multirow{2}{*}{4} & $\mathrm{C}_{2} \mathrm{H}_{5}$ & 1 & 95 & $19 / 81$ & 84 & $76 / 24$ \\
\hline & $\mathrm{n}-\mathrm{C}_{4} \mathrm{H}_{9}$ & 2 & 97 & $16 / 84$ & 86 & $80 / 20$ \\
\hline \multirow{2}{*}{$\mathrm{Cl}-1$} & $\mathrm{C}_{2} \mathrm{H}_{5}$ & 3 & 73 & $26 / 74$ & 69 & $80 / 20$ \\
\hline & $\mathrm{n}-\mathrm{C}_{4} \mathrm{H}_{9}$ & 4 & 73 & $26 / 74$ & 70 & $80 / 20$ \\
\hline \multirow{2}{*}{$\mathrm{H}_{3} \mathrm{C}-$} & $\mathrm{C}_{2} \mathrm{H}_{5}$ & 5 & 42 & $27 / 73$ & 52 & $68 / 32$ \\
\hline & $\mathrm{n}-\mathrm{C}_{4} \mathrm{H}_{9}$ & 6 & 44 & $24 / 76$ & 55 & $66 / 34$ \\
\hline \multirow{2}{*}{$\mathrm{H}_{3} \mathrm{CO}-1$} & $\mathrm{C}_{2} \mathrm{H}_{5}$ & 7 & 36 & $18 / 72$ & 30 & $69 / 31$ \\
\hline & $\mathrm{n}-\mathrm{C}_{4} \mathrm{H}_{9}$ & 8 & 40 & $25 / 75$ & 33 & $74 / 26$ \\
\hline \multirow[t]{2}{*}{1} & $\mathrm{C}_{2} \mathrm{H}_{5}$ & 9 & 93 & $25 / 75$ & 68 & $70 / 30$ \\
\hline & $\mathrm{n}-\mathrm{C}_{4} \mathrm{H}_{9}$ & 10 & 95 & $20 / 80$ & 70 & $77 / 23$ \\
\hline \multirow{2}{*}{$\mathrm{H}_{3} \mathrm{C}$} & $\mathrm{C}_{2} \mathrm{H}_{5}$ & 11 & 60 & $26 / 74$ & 62 & $75 / 25$ \\
\hline & n- $\mathrm{C}_{4} \mathrm{H}_{9}$ & 12 & 64 & $22 / 78$ & 66 & $78 / 22$ \\
\hline
\end{tabular}

* Water $(2 \mathrm{mmol})$ is added. ** $2 \mathrm{~mL}$ methanol with $0.18 \mathrm{mmol}$ water.

Table 6. Effect of the aliphatic chain of the aldehyde on the Wittig reaction

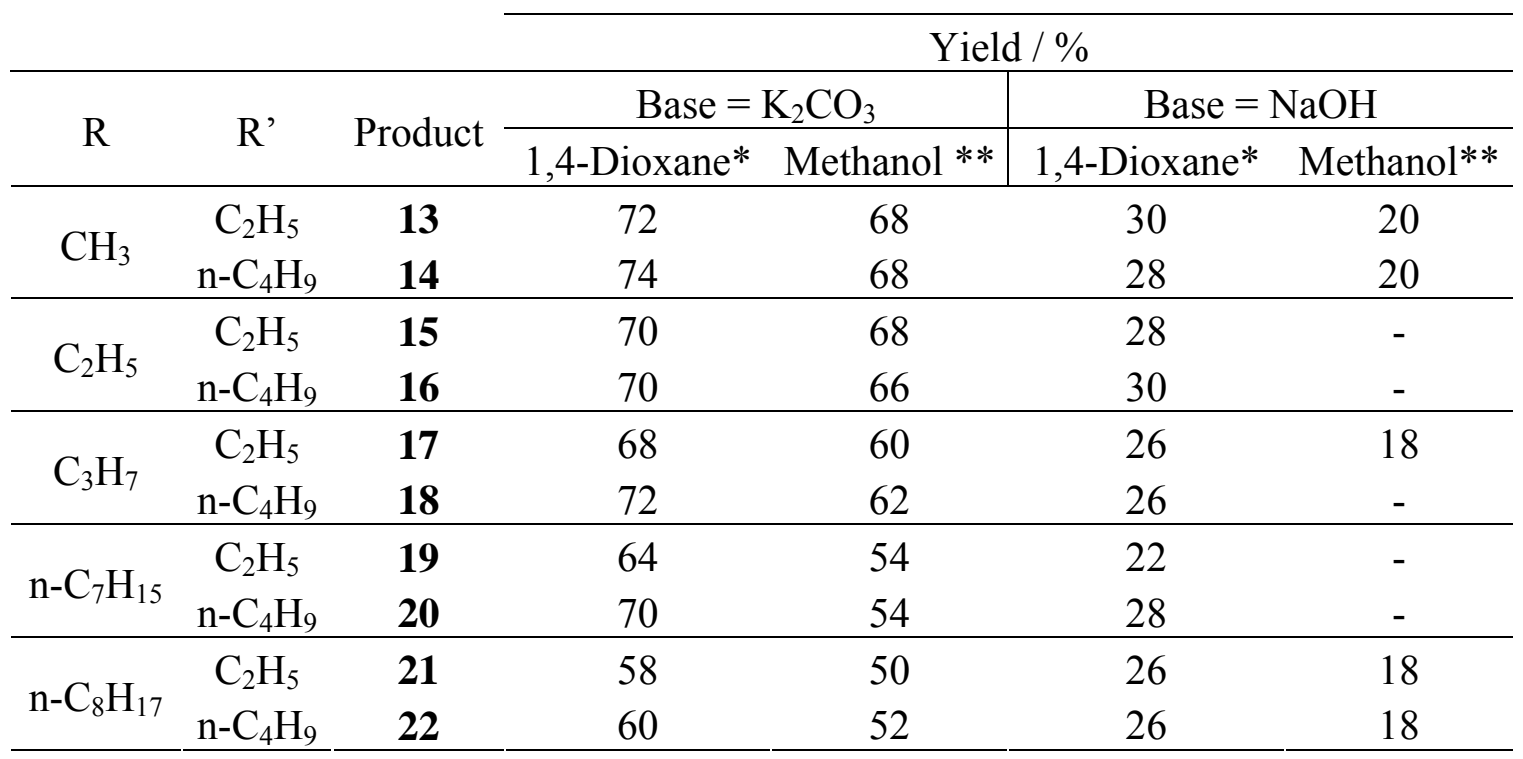

* Water $(2 \mathrm{mmol})$ is added. ** Methanol $(2 \mathrm{~mL})$ with $0.18 \mathrm{mmol}$ water. 


\section{Ketones}

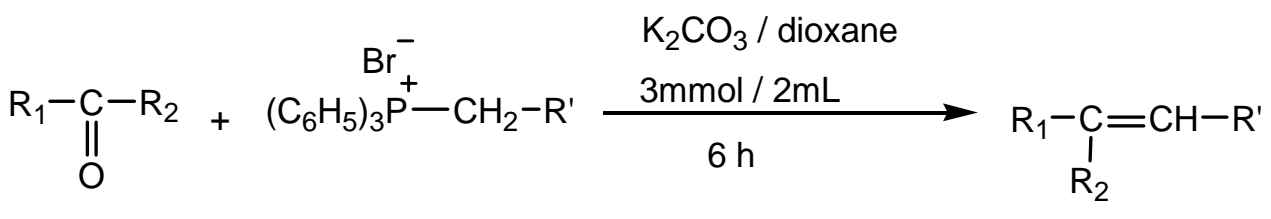

$2 \mathrm{mmol} \quad 2.5 \mathrm{mmol}$

Wittig reactions involving acetophenone, 3-pentanone or cyclohexanone failed. Clearly, ketones are not reactive. The unreactivity is due to the low electrophilic character of the $\mathrm{C}=\mathrm{O}$ bond and, very probably, steric effects. There is an exception, however, as a strong electron demanding group such as $\mathrm{CF}_{3}$ increases the reactivity ( $95 \%$ yield). The results confirm the determining role of the electrophilicity of the carbon in the $\mathrm{C}=\mathrm{O}$ bond toward the ylide.

Table 7. Condensation of ketones with various phosphonium salts

\begin{tabular}{cccc}
\hline $\mathrm{R}_{1}$ & $\mathrm{R}_{2}$ & $\mathrm{R}^{\prime}$ & Yield /\% \\
\hline \multirow{2}{*}{$\mathrm{C}_{2} \mathrm{H}_{5}$} & \multirow{2}{*}{$\mathrm{C}_{2} \mathrm{H}_{5}$} & $\mathrm{C}_{2} \mathrm{H}_{5}$ & 0 \\
& & $\mathrm{C}_{4} \mathrm{H}_{9}$ & 0 \\
\hline \multirow{2}{*}{$-\left(\mathrm{CH}_{2}\right)_{5-}^{-}$} & & $\mathrm{C}_{2} \mathrm{H}_{5}$ & 0 \\
& & $\mathrm{C}_{4} \mathrm{H}_{9}$ & 0 \\
\hline \multirow{2}{*}{$\mathrm{C}_{6} \mathrm{H}_{5}$} & \multirow{2}{*}{$\mathrm{CH}_{3}$} & $\mathrm{C}_{2} \mathrm{H}_{5}$ & 0 \\
& & $\mathrm{C}_{4} \mathrm{H}_{9}$ & 0 \\
\hline \multirow{2}{*}{$\mathrm{p} \mathrm{NO}_{2}-\mathrm{C}_{6} \mathrm{H}_{4}$} & \multirow{2}{*}{$\mathrm{CH}_{3}$} & $\mathrm{C}_{2} \mathrm{H}_{5}$ & 0 \\
& & $\mathrm{C}_{4} \mathrm{H}_{9}$ & 0 \\
\hline \multirow{2}{*}{$\mathrm{C}_{6} \mathrm{H}_{5}$} & \multirow{2}{*}{$\mathrm{CF}_{3}$} & $\mathrm{C}_{2} \mathrm{H}_{5}$ & 93 \\
& & $\mathrm{C}_{4} \mathrm{H}_{9}$ & 95 \\
\hline
\end{tabular}

Effect of the phase-transfer catalyst

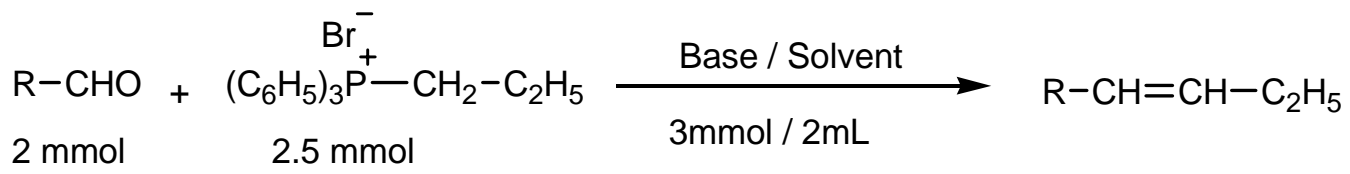

As observed, the addition of a phase transfer catalyst such as tetraalkylammonium salts or crown ethers is highly beneficial for the reactivity in organic solvents. This is no more the case in aqueous media. The catalyst leads to an exaltation of the basicity of carbonate ions via ionic exchange equilibria of $\mathrm{K}^{+}$or $\mathrm{Na}^{+}$with $\left(\mathrm{R}_{4}\right) \mathrm{N}^{+}$or via complexation of the metal cations $\left(\mathrm{K}^{+}\right.$or $\mathrm{Na}^{+}$) by crown ethers : 


$$
\begin{gathered}
\mathrm{M}_{2} \mathrm{CO}_{3} \text { solid }+2 \mathrm{Bu}_{4} \mathrm{~N}^{+} \mathrm{Br} \rightleftharpoons\left(\mathrm{Bu}_{4} \mathrm{~N}^{+}\right)_{2} \mathrm{CO}_{3}^{2-}+2 \mathrm{MBr} \\
\mathrm{M}_{2} \mathrm{CO}_{3} \text { Solid } \\
\mathrm{M}=\mathrm{K} \text { or Na}
\end{gathered}
$$

In reactions involving sodium hydroxide as the base, the ionic exchange equilibrium leads to the formation of a tetraalkylammonium hydroxide.

$\mathrm{NaOH}+\mathrm{But}_{4} \mathrm{~N}^{+} \mathrm{Br}^{-} \rightleftharpoons \mathrm{But}_{4} \mathrm{~N}^{+} \mathrm{HO}^{-}+\mathrm{NaBr}$

With $\mathrm{Bu}_{4} \mathrm{~N}^{+} \mathrm{Br}^{-}$, the active base would be $\mathrm{Bu}_{4} \mathrm{~N}^{+} \mathrm{OH}^{-}$so that the cation could no more be associated with the carbonyl. The $\mathrm{OH}^{-}$ions abstract the acidic hydrogen of the phosphonium salt, decreasing the rate of secondary reactions (Cannizzaro and aldol condensations). The phenomenon is clearly observed with aromatic aldehydes. Conversely, the aldol reaction could progress in concert with the Wittig reaction owing to the possibility of abstraction of an $\alpha$-proton of the carbonyl group in the case of aliphatic aldehydes. 
Table 8. Effect of the PT catalyst in the condensation of propyltriphenylphosphonium bromide and various aldehydes with potassium carbonate as the base

\begin{tabular}{|c|c|c|c|c|}
\hline Solvent & Time & Additive & $\mathrm{R}$ & Yield / \% \\
\hline \multirow{12}{*}{ Water } & \multirow{12}{*}{$24 \mathrm{~h}$} & \multirow{3}{*}{ - } & $\mathrm{C}_{6} \mathrm{H}_{5}$ & 78 \\
\hline & & & $\mathrm{Cl}-\mathrm{C}_{6} \mathrm{H}_{4}$ & 64 \\
\hline & & & $\mathrm{n}-\mathrm{C}_{8} \mathrm{H}_{17}$ & 32 \\
\hline & & \multirow{3}{*}{ НТМАВ } & $\mathrm{C}_{6} \mathrm{H}_{5}$ & 50 \\
\hline & & & $\mathrm{Cl}-\mathrm{C}_{6} \mathrm{H}_{4}$ & 46 \\
\hline & & & $\mathrm{n}-\mathrm{C}_{8} \mathrm{H}_{17}$ & 20 \\
\hline & & \multirow{3}{*}{ TBAB } & $\mathrm{C}_{6} \mathrm{H}_{5}$ & 52 \\
\hline & & & $\mathrm{Cl}-\mathrm{C}_{6} \mathrm{H}_{4}$ & 45 \\
\hline & & & $\mathrm{n}-\mathrm{C}_{8} \mathrm{H}_{17}$ & 20 \\
\hline & & \multirow{3}{*}{$\begin{array}{c}\text { Dicyclohexano- } \\
\text { 18-crown-6 }\end{array}$} & $\mathrm{C}_{6} \mathrm{H}_{5}$ & 54 \\
\hline & & & $\mathrm{Cl}-\mathrm{C}_{6} \mathrm{H}_{4}$ & 48 \\
\hline & & & $\mathrm{n}-\mathrm{C}_{8} \mathrm{H}_{17}$ & 19 \\
\hline \multirow{9}{*}{ Dioxane } & \multirow{9}{*}{$3 \mathrm{~h}$} & \multirow{3}{*}{-} & $\mathrm{C}_{6} \mathrm{H}_{5}$ & 72 \\
\hline & & & $\mathrm{Cl}-\mathrm{C}_{6} \mathrm{H}_{4}$ & 62 \\
\hline & & & $\mathrm{n}-\mathrm{C}_{8} \mathrm{H}_{17}$ & 44 \\
\hline & & \multirow{3}{*}{ TBAB } & $\mathrm{C}_{6} \mathrm{H}_{5}$ & 88 \\
\hline & & & $\mathrm{Cl}-\mathrm{C}_{6} \mathrm{H}_{4}$ & 77 \\
\hline & & & $\mathrm{n}-\mathrm{C}_{8} \mathrm{H}_{17}$ & 64 \\
\hline & & \multirow{3}{*}{$\begin{array}{c}\text { Dicyclohexano- } \\
\text { 18-crown-6 }\end{array}$} & $\mathrm{C}_{6} \mathrm{H}_{5}$ & 93 \\
\hline & & & $\mathrm{Cl}-\mathrm{C}_{6} \mathrm{H}_{4}$ & 81 \\
\hline & & & $\mathrm{n}-\mathrm{C}_{8} \mathrm{H}_{17}$ & 62 \\
\hline \multirow{9}{*}{ Methanol } & \multirow{9}{*}{$3 \mathrm{~h}$} & \multirow{3}{*}{-} & $\mathrm{C}_{6} \mathrm{H}_{5}$ & 84 \\
\hline & & & $\mathrm{Cl}-\mathrm{C}_{6} \mathrm{H}_{4}$ & 79 \\
\hline & & & $\mathrm{n}-\mathrm{C}_{8} \mathrm{H}_{17}$ & 52 \\
\hline & & \multirow{3}{*}{ TBAB } & $\mathrm{C}_{6} \mathrm{H}_{5}$ & 87 \\
\hline & & & $\mathrm{Cl}-\mathrm{C}_{6} \mathrm{H}_{4}$ & 85 \\
\hline & & & $\mathrm{n}-\mathrm{C}_{8} \mathrm{H}_{17}$ & 73 \\
\hline & & \multirow{3}{*}{$\begin{array}{c}\text { Dicyclohexano- } \\
\text { 18-crown-6 }\end{array}$} & $\mathrm{C}_{6} \mathrm{H}_{5}$ & 88 \\
\hline & & & $\mathrm{Cl}-\mathrm{C}_{6} \mathrm{H}_{4}$ & 83 \\
\hline & & & $\mathrm{n}-\mathrm{C}_{8} \mathrm{H}_{17}$ & 75 \\
\hline \multirow{6}{*}{$\begin{array}{l}\text { Dichloro- } \\
\text { methane }\end{array}$} & \multirow{6}{*}{$3 \mathrm{~h}$} & \multirow{3}{*}{-} & $\mathrm{C}_{6} \mathrm{H}_{5}$ & 20 \\
\hline & & & $\mathrm{Cl}-\mathrm{C}_{6} \mathrm{H}_{4}$ & 17 \\
\hline & & & $\mathrm{n}-\mathrm{C}_{8} \mathrm{H}_{17}$ & 10 \\
\hline & & \multirow{3}{*}{$\begin{array}{c}\text { Dicyclohexano- } \\
\text { 18-crown-6 }\end{array}$} & $\mathrm{C}_{6} \mathrm{H}_{5}$ & 39 \\
\hline & & & $\mathrm{Cl}-\mathrm{C}_{6} \mathrm{H}_{4}$ & 31 \\
\hline & & & $\mathrm{n}-\mathrm{C}_{8} \mathrm{H}_{17}$ & 30 \\
\hline
\end{tabular}

HTMAB, Hexadecyltrimethylammonium bromide; TBAB, Tetrabutylammonium bromide. 
Table 9. Effect of the PT catalyst in the condensation of propyltriphenylphosphonium bromide and various aldehydes with various bases

\begin{tabular}{|c|c|c|c|}
\hline Solvent/Base & Additive & $\mathrm{R}$ & Yield / \% \\
\hline \multirow{9}{*}{$\begin{array}{c}\text { Dioxane/NaOH } \\
{[3 \mathrm{~h}]}\end{array}$} & \multirow[t]{3}{*}{ ( } & $\mathrm{C}_{6} \mathrm{H}_{5}$ & 40 \\
\hline & & $\mathrm{Cl}-\mathrm{C}_{6} \mathrm{H}_{4}$ & 35 \\
\hline & & $\mathrm{n}-\mathrm{C}_{8} \mathrm{H}_{17}$ & 26 \\
\hline & \multirow{3}{*}{ TBAB } & $\mathrm{C}_{6} \mathrm{H}_{5}$ & 84 \\
\hline & & $\mathrm{Cl}-\mathrm{C}_{6} \mathrm{H}_{4}$ & 73 \\
\hline & & $\mathrm{n}-\mathrm{C}_{8} \mathrm{H}_{17}$ & 59 \\
\hline & \multirow{3}{*}{$\begin{array}{c}\text { Dicyclohexano- } \\
\text { 18-crown-6 }\end{array}$} & $\mathrm{C}_{6} \mathrm{H}_{5}$ & 44 \\
\hline & & $\mathrm{Cl}-\mathrm{C}_{6} \mathrm{H}_{4}$ & 37 \\
\hline & & $\mathrm{n}-\mathrm{C}_{8} \mathrm{H}_{17}$ & 27 \\
\hline \multirow{9}{*}{$\begin{array}{c}\text { Methanol/NaOH } \\
{[3 \mathrm{~h}]}\end{array}$} & \multirow{3}{*}{-} & $\mathrm{C}_{6} \mathrm{H}_{5}$ & 32 \\
\hline & & $\mathrm{Cl}-\mathrm{C}_{6} \mathrm{H}_{4}$ & 24 \\
\hline & & $\mathrm{n}-\mathrm{C}_{8} \mathrm{H}_{17}$ & 18 \\
\hline & \multirow{3}{*}{ TBAB } & $\mathrm{C}_{6} \mathrm{H}_{5}$ & 82 \\
\hline & & $\mathrm{Cl}-\mathrm{C}_{6} \mathrm{H}_{4}$ & 69 \\
\hline & & $\mathrm{n}-\mathrm{C}_{8} \mathrm{H}_{17}$ & 34 \\
\hline & \multirow{3}{*}{$\begin{array}{c}\text { Dicyclohexano- } \\
\text { 18-crown-6 }\end{array}$} & $\mathrm{C}_{6} \mathrm{H}_{5}$ & 52 \\
\hline & & $\mathrm{Cl}-\mathrm{C}_{6} \mathrm{H}_{4}$ & 44 \\
\hline & & $\mathrm{n}-\mathrm{C}_{8} \mathrm{H}_{17}$ & 34 \\
\hline \multirow{6}{*}{$\begin{array}{c}\text { Methanol/ } \mathrm{Na}_{2} \mathrm{CO}_{3} \\
{[3 \mathrm{~h}]}\end{array}$} & \multirow{3}{*}{-} & $\mathrm{C}_{6} \mathrm{H}_{5}$ & 15 \\
\hline & & $\mathrm{Cl}-\mathrm{C}_{6} \mathrm{H}_{4}$ & 10 \\
\hline & & $\mathrm{n}-\mathrm{C}_{8} \mathrm{H}_{17}$ & 8 \\
\hline & \multirow{3}{*}{ TBAB } & $\mathrm{C}_{6} \mathrm{H}_{5}$ & 71 \\
\hline & & $\mathrm{Cl}-\mathrm{C}_{6} \mathrm{H}_{4}$ & 62 \\
\hline & & $\mathrm{n}-\mathrm{C}_{8} \mathrm{H}_{17}$ & 56 \\
\hline
\end{tabular}

\section{Activation on alumina}

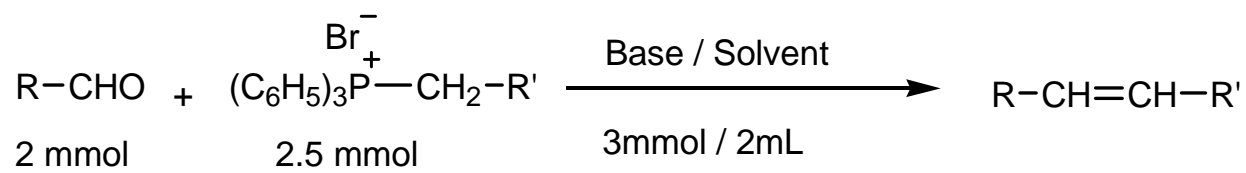

Table 10 reports the results. Sodium hydroxide adsorbed on alumina activates the Wittig reaction at the same level as it does in dioxane. The addition of a phase-transfer catalyst decreases the yield, with apparent prevalence of Cannizzaro and aldol reactions. The ammonium cation of the PT catalyst and its complexation with the carbonyl group increases the electrophilicity of the carbon and favors the nucleophilic attack of the hydroxide ion, yielding the Cannizzaro product, 
or the aldol product in the case of enolizable aldehydes. In addition, the ylide formed after abstraction of the acidic hydrogen of the phosphine salt is adsorbed and seemingly fixed on the alumina surface.

Table 10. Effect of the medium on the Wittig reaction

\begin{tabular}{|c|c|c|c|}
\hline Medium [time] & $\mathrm{R}$ & $\mathrm{R}^{\prime}$ & Yield / \% \\
\hline \multirow{6}{*}{$\begin{array}{c}\mathrm{NaOH} / \text { Dioxane }(*) \\
{[3 \mathrm{~h}]}\end{array}$} & \multirow{2}{*}{$\mathrm{C}_{6} \mathrm{H}_{5}$} & $\mathrm{C}_{2} \mathrm{H}_{5}$ & 40 \\
\hline & & $\mathrm{C}_{4} \mathrm{H}_{9}$ & 42 \\
\hline & \multirow{2}{*}{$\mathrm{Cl}-\mathrm{C}_{6} \mathrm{H}_{4}$} & $\mathrm{C}_{2} \mathrm{H}_{5}$ & 35 \\
\hline & & $\mathrm{C}_{4} \mathrm{H}_{9}$ & 35 \\
\hline & \multirow{2}{*}{$\mathrm{n}-\mathrm{C}_{8} \mathrm{H}_{17}$} & $\mathrm{C}_{2} \mathrm{H}_{5}$ & 18 \\
\hline & & $\mathrm{C}_{4} \mathrm{H}_{9}$ & 18 \\
\hline \multirow{6}{*}{$\begin{array}{c}\mathrm{NaOH} / \mathrm{Methanol} \\
{[3 \mathrm{~h}]}\end{array}$} & \multirow{2}{*}{$\mathrm{C}_{6} \mathrm{H}_{5}$} & $\mathrm{C}_{2} \mathrm{H}_{5}$ & 32 \\
\hline & & $\mathrm{C}_{4} \mathrm{H}_{9}$ & 33 \\
\hline & \multirow{2}{*}{$\mathrm{Cl}-\mathrm{C}_{6} \mathrm{H}_{4}$} & $\mathrm{C}_{2} \mathrm{H}_{5}$ & 24 \\
\hline & & $\mathrm{C}_{4} \mathrm{H}_{9}$ & 24 \\
\hline & \multirow{2}{*}{$\mathrm{n}-\mathrm{C}_{8} \mathrm{H}_{17}$} & $\mathrm{C}_{2} \mathrm{H}_{5}$ & 18 \\
\hline & & $\mathrm{C}_{4} \mathrm{H}_{9}$ & 18 \\
\hline \multirow{6}{*}{$\begin{array}{l}\mathrm{Al}_{2} \mathrm{O}_{3} \\
{[60 \mathrm{~h}]}\end{array}$} & \multirow{2}{*}{$\mathrm{C}_{6} \mathrm{H}_{5}$} & $\mathrm{C}_{2} \mathrm{H}_{5}$ & 0 \\
\hline & & $\mathrm{C}_{4} \mathrm{H}_{9}$ & 0 \\
\hline & \multirow{2}{*}{$\mathrm{Cl}-\mathrm{C}_{6} \mathrm{H}_{4}$} & $\mathrm{C}_{2} \mathrm{H}_{5}$ & 0 \\
\hline & & $\mathrm{C}_{4} \mathrm{H}_{9}$ & 0 \\
\hline & \multirow{2}{*}{$\mathrm{n}-\mathrm{C}_{8} \mathrm{H}_{17}$} & $\mathrm{C}_{2} \mathrm{H}_{5}$ & 0 \\
\hline & & $\mathrm{C}_{4} \mathrm{H}_{9}$ & 0 \\
\hline \multirow{6}{*}{$\begin{array}{c}\mathrm{NaOH} / \mathrm{Al}_{2} \mathrm{O}_{3} \\
{[12 \mathrm{~h}]}\end{array}$} & \multirow{2}{*}{$\mathrm{C}_{6} \mathrm{H}_{5}$} & $\mathrm{C}_{2} \mathrm{H}_{5}$ & 50 \\
\hline & & $\mathrm{C}_{4} \mathrm{H}_{9}$ & 51 \\
\hline & \multirow{2}{*}{$\mathrm{Cl}-\mathrm{C}_{6} \mathrm{H}_{4}$} & $\mathrm{C}_{2} \mathrm{H}_{5}$ & 45 \\
\hline & & $\mathrm{C}_{4} \mathrm{H}_{9}$ & 46 \\
\hline & \multirow{2}{*}{$\mathrm{n}-\mathrm{C}_{8} \mathrm{H}_{17}$} & $\mathrm{C}_{2} \mathrm{H}_{5}$ & 34 \\
\hline & & $\mathrm{C}_{4} \mathrm{H}_{9}$ & 35 \\
\hline \multirow{6}{*}{$\begin{array}{c}\mathrm{NaOH} / \mathrm{Al}_{2} \mathrm{O}_{3} \\
+ \\
\text { Aliquat-336 } \\
{[12 \mathrm{~h}]}\end{array}$} & \multirow{2}{*}{$\mathrm{C}_{6} \mathrm{H}_{5}$} & $\mathrm{C}_{2} \mathrm{H}_{5}$ & 26 \\
\hline & & $\mathrm{C}_{4} \mathrm{H}_{9}$ & 25 \\
\hline & \multirow{2}{*}{$\mathrm{Cl}-\mathrm{C}_{6} \mathrm{H}_{4}$} & $\mathrm{C}_{2} \mathrm{H}_{5}$ & 17 \\
\hline & & $\mathrm{C}_{4} \mathrm{H}_{9}$ & 15 \\
\hline & \multirow{2}{*}{$\mathrm{n}-\mathrm{C}_{8} \mathrm{H}_{17}$} & $\mathrm{C}_{2} \mathrm{H}_{5}$ & 14 \\
\hline & & $\mathrm{C}_{4} \mathrm{H}_{9}$ & 14 \\
\hline \multirow{6}{*}{$\begin{array}{c}\mathrm{NaOH} / \mathrm{Al}_{2} \mathrm{O}_{3} \\
+ \\
\mathrm{HTMAB} \\
{[12 \mathrm{~h}]}\end{array}$} & \multirow{2}{*}{$\mathrm{C}_{6} \mathrm{H}_{5}$} & $\mathrm{C}_{2} \mathrm{H}_{5}$ & 24 \\
\hline & & $\mathrm{C}_{4} \mathrm{H}_{9}$ & 24 \\
\hline & \multirow{2}{*}{$\mathrm{Cl}-\mathrm{C}_{6} \mathrm{H}_{4}$} & $\mathrm{C}_{2} \mathrm{H}_{5}$ & 18 \\
\hline & & $\mathrm{C}_{4} \mathrm{H}_{9}$ & 17 \\
\hline & \multirow{2}{*}{$\mathrm{n}-\mathrm{C}_{8} \mathrm{H}_{17}$} & $\mathrm{C}_{2} \mathrm{H}_{5}$ & 14 \\
\hline & & $\mathrm{C}_{4} \mathrm{H}_{9}$ & 13 \\
\hline
\end{tabular}

* Water, 2 mmol, is added. 


\section{Effect on the isomer distribution}

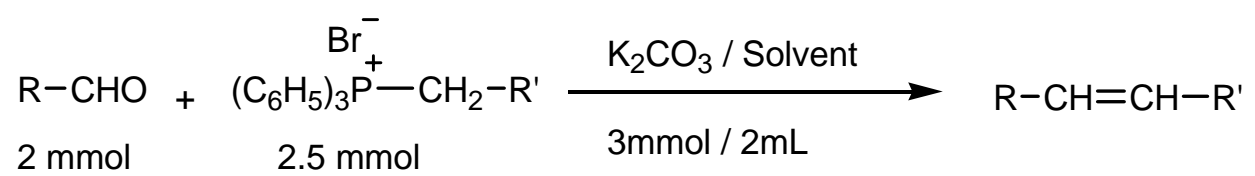

The solvent is a major parameter for the stereochemical outcome in the Wittig reaction. The $(E)$ olefin percentage increases in a polar medium. In a protic solvent like methanol the dominant $(E)$ isomer suggests preferential formation of the threo betaine $e^{21,32}$ as a consequence of the solvation of ionic species, more precisely, the reactivity of the ylide towards the aldehyde. It is magnified by the hydrogen bonds between the ylide and the molecules of solvent. The preferential formation of the threo betaine, which is stabilized by hydrogen bonds, contrary to the oxaphosphetane leads to the formation of the $(E)$ - olefin. In an apolar medium, coordination of the $\mathrm{O}$ atom of the aldehyde and the $\mathrm{P}$ atom of the ylide is promoted. This means formation of an $\mathrm{O}-\mathrm{P}$ bond prior to the $\mathrm{C}-\mathrm{C}$ bond (Scheme 3). The structure of the intermediate acknowledges the location of an aldehyde group (phenyl) in a least sterically congested position so that the alkyl group (ethyl) of the ylide interacts with a phenyl group of the phosphine. The formation of oxaphosphetane requires rotation around the $\mathrm{C}-\mathrm{O}$ bond, promoting the erythro configuration of the oxaphosphetane and, consequently, the $(Z)$ olefin. It seems that the oxaphosphetane-forming step is believed to resemble a concerted [2+2] cycloaddition between the ylide and the carbonyl compound, ${ }^{33}$ then it can open to zwitterions which are free to rotate to the thermodynamically more stable threo isomers before decomposing to products. ${ }^{32}$

In contrast, the threo configuration is disfavored as a consequence of high steric hindrance imposed by the interactions between the aldehyde group and a phenyl group of the phosphine as well as between the alkyl group of the aldehyde and the phenyl group of the phosphine (Scheme 3). Table 11 indicates that selecting dichloromethane as the solvent in the presence of water, or phase-transfer agents such as crown-ethers, leads to olefins with a $(Z)$ : $(E)$ ratio close to unity. It is worthwhile underlining the synthesis of $(Z)$ olefins by using an apolar aprotic weakly hydrated medium via a solid-liquid transfer process.

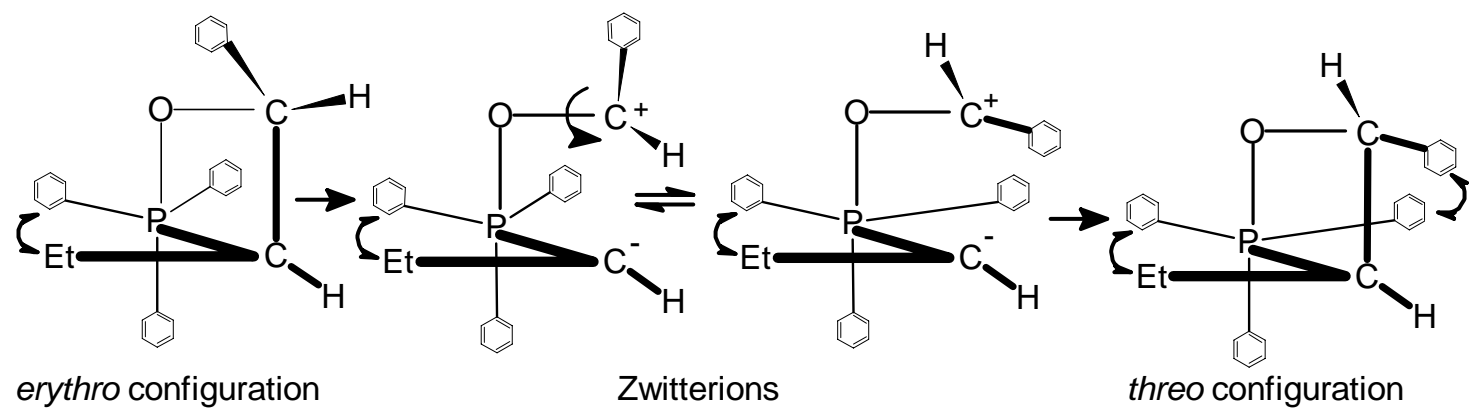

\section{Scheme 3}


Table 11. Effect of the medium on the $E / Z$ ratio

\begin{tabular}{|c|c|c|c|}
\hline Medium & $\mathrm{R}^{\prime}$ & $\mathrm{R}$ & $E / Z^{\mathrm{a}, \mathrm{b}}$ \\
\hline \multirow{6}{*}{$\begin{array}{l}\text { Acetonitrile } / 2 \mathrm{mmol} \text { water } / 80^{\circ} \mathrm{C} \\
2 \mathrm{~h}\end{array}$} & \multirow{3}{*}{$\mathrm{C}_{2} \mathrm{H}_{5}$} & $\mathrm{C}_{6} \mathrm{H}_{5}$ & $43 / 57$ \\
\hline & & $\mathrm{Cl}-\mathrm{C}_{6} \mathrm{H}_{4}$ & $46 / 54$ \\
\hline & & $\mathrm{n}-\mathrm{C}_{8} \mathrm{H}_{17}$ & $41 / 59$ \\
\hline & \multirow{3}{*}{$\mathrm{C}_{4} \mathrm{H}_{9}$} & $\mathrm{C}_{6} \mathrm{H}_{5}$ & $45 / 55$ \\
\hline & & $\mathrm{Cl}-\mathrm{C}_{6} \mathrm{H}_{4}$ & $45 / 55$ \\
\hline & & $\mathrm{n}-\mathrm{C}_{8} \mathrm{H}_{17}$ & $42 / 58$ \\
\hline \multirow{6}{*}{$\begin{array}{c}\text { Dioxane } / 2 \mathrm{mmol} \text { water } / 95^{\circ} \mathrm{C} \\
3 \mathrm{~h}\end{array}$} & \multirow{3}{*}{$\mathrm{C}_{2} \mathrm{H}_{5}$} & $\mathrm{C}_{6} \mathrm{H}_{5}$ & $19 / 81$ \\
\hline & & $\mathrm{Cl}-\mathrm{C}_{6} \mathrm{H}_{4}$ & $26 / 74$ \\
\hline & & $\mathrm{n}-\mathrm{C}_{8} \mathrm{H}_{17}$ & $26 / 74$ \\
\hline & \multirow{3}{*}{$\mathrm{C}_{4} \mathrm{H}_{9}$} & $\mathrm{C}_{6} \mathrm{H}_{5}$ & $16 / 84$ \\
\hline & & $\mathrm{Cl}-\mathrm{C}_{6} \mathrm{H}_{4}$ & $26 / 74$ \\
\hline & & $\mathrm{n}-\mathrm{C}_{8} \mathrm{H}_{17}$ & $25 / 75$ \\
\hline \multirow{6}{*}{$\begin{array}{c}\text { Methanol } / 65^{\circ} \mathrm{C} \\
3 \mathrm{~h}\end{array}$} & \multirow{3}{*}{$\mathrm{C}_{2} \mathrm{H}_{5}$} & $\mathrm{C}_{6} \mathrm{H}_{5}$ & $76 / 24$ \\
\hline & & $\mathrm{Cl}-\mathrm{C}_{6} \mathrm{H}_{4}$ & $80 / 20$ \\
\hline & & $\mathrm{n}-\mathrm{C}_{8} \mathrm{H}_{17}$ & $82 / 18$ \\
\hline & \multirow{3}{*}{$\mathrm{C}_{4} \mathrm{H}_{9}$} & $\mathrm{C}_{6} \mathrm{H}_{5}$ & $80 / 20$ \\
\hline & & $\mathrm{Cl}-\mathrm{C}_{6} \mathrm{H}_{4}$ & $80 / 20$ \\
\hline & & $\mathrm{n}-\mathrm{C}_{8} \mathrm{H}_{17}$ & $85 / 15$ \\
\hline \multirow{6}{*}{$\begin{array}{c}\mathrm{CH}_{2} \mathrm{Cl}_{2} / 40^{\circ} \mathrm{C} / \\
0.1 \mathrm{mmol} \\
\text { dicyclohexano-18-crown-6 } \\
3 \mathrm{~h}\end{array}$} & \multirow{3}{*}{$\mathrm{C}_{2} \mathrm{H}_{5}$} & $\mathrm{C}_{6} \mathrm{H}_{5}$ & $52 / 48$ \\
\hline & & $\mathrm{Cl}-\mathrm{C}_{6} \mathrm{H}_{4}$ & $50 / 50$ \\
\hline & & $\mathrm{n}-\mathrm{C}_{8} \mathrm{H}_{17}$ & $51 / 49$ \\
\hline & \multirow{3}{*}{$\mathrm{C}_{4} \mathrm{H}_{9}$} & $\mathrm{C}_{6} \mathrm{H}_{5}$ & $54 / 46$ \\
\hline & & $\mathrm{Cl}-\mathrm{C}_{6} \mathrm{H}_{4}$ & $52 / 48$ \\
\hline & & $\mathrm{n}-\mathrm{C}_{8} \mathrm{H}_{17}$ & $55 / 45$ \\
\hline \multirow{6}{*}{$\begin{array}{c}\mathrm{CH}_{2} \mathrm{Cl}_{2} / 2 \mathrm{mmol} \text { water } / 40^{\circ} \mathrm{C} \\
3 \mathrm{~h}\end{array}$} & \multirow{3}{*}{$\mathrm{C}_{2} \mathrm{H}_{5}$} & $\mathrm{C}_{6} \mathrm{H}_{5}$ & $50 / 50$ \\
\hline & & $\mathrm{Cl}-\mathrm{C}_{6} \mathrm{H}_{4}$ & $49 / 51$ \\
\hline & & $\mathrm{n}-\mathrm{C}_{8} \mathrm{H}_{17}$ & $52 / 48$ \\
\hline & \multirow{3}{*}{$\mathrm{C}_{4} \mathrm{H}_{9}$} & $\mathrm{C}_{6} \mathrm{H}_{5}$ & $52 / 48$ \\
\hline & & $\mathrm{Cl}-\mathrm{C}_{6} \mathrm{H}_{4}$ & $52 / 48$ \\
\hline & & $\mathrm{n}-\mathrm{C}_{8} \mathrm{H}_{17}$ & $53 / 47$ \\
\hline \multirow{6}{*}{$\begin{array}{c}\text { Hexane } / 65^{\circ} \mathrm{C} \\
3 \mathrm{~h}\end{array}$} & \multirow{3}{*}{$\mathrm{C}_{2} \mathrm{H}_{5}$} & $\mathrm{C}_{6} \mathrm{H}_{5}$ & $18 / 82$ \\
\hline & & $\mathrm{Cl}-\mathrm{C}_{6} \mathrm{H}_{4}$ & $20 / 80$ \\
\hline & & $\mathrm{n}-\mathrm{C}_{8} \mathrm{H}_{17}$ & $19 / 81$ \\
\hline & \multirow{3}{*}{$\mathrm{C}_{4} \mathrm{H}_{9}$} & $\mathrm{C}_{6} \mathrm{H}_{5}$ & $21 / 79$ \\
\hline & & $\mathrm{Cl}-\mathrm{C}_{6} \mathrm{H}_{4}$ & $19 / 81$ \\
\hline & & $\mathrm{n}-\mathrm{C}_{8} \mathrm{H}_{17}$ & $23 / 77$ \\
\hline
\end{tabular}




\begin{tabular}{|c|c|c|c|}
\hline \multirow{6}{*}{$\begin{array}{c}\text { Water } / 100^{\circ} \mathrm{C} \\
24 \mathrm{~h}\end{array}$} & \multirow{3}{*}{$\mathrm{C}_{2} \mathrm{H}_{5}$} & $\mathrm{C}_{6} \mathrm{H}_{5}$ & $88 / 12$ \\
\hline & & $\mathrm{Cl}-\mathrm{C}_{6} \mathrm{H}_{4}$ & $89 / 11$ \\
\hline & & $\mathrm{n}-\mathrm{C}_{8} \mathrm{H}_{17}$ & $87 / 13$ \\
\hline & \multirow{3}{*}{$\mathrm{C}_{4} \mathrm{H}_{9}$} & $\mathrm{C}_{6} \mathrm{H}_{5}$ & $90 / 10$ \\
\hline & & $\mathrm{Cl}-\mathrm{C}_{6} \mathrm{H}_{4}$ & $88 / 12$ \\
\hline & & $\mathrm{n}-\mathrm{C}_{8} \mathrm{H}_{17}$ & $90 / 10$ \\
\hline
\end{tabular}

${ }^{a}$ Determined by ${ }^{1} \mathrm{H}-\mathrm{NMR}$ of the product. ${ }^{\mathrm{b}}$ In the ${ }^{1} \mathrm{H}-\mathrm{NMR}$ the system ${ }_{\mathrm{CH}}^{\mathrm{A}}={ }_{\mathrm{CH}}^{\mathrm{B}}-\mathrm{CH}_{2}$ gives the following characteristic values: for the $E$-isomer $J_{H_{A} H_{B}}=15.6( \pm 0.3) \mathrm{Hz}, J_{H_{B} H_{X}}=6.9( \pm 0.3) \mathrm{Hz}$, for the $Z$-isomer $J_{H_{A} H_{B}}=11.4( \pm 0.3) \mathrm{Hz}, J_{H_{B} H_{X}}=6.9( \pm 0.3) \mathrm{Hz}$. In the ${ }^{13} \mathrm{C}$-NMR, the values of the chemical displacements of $\alpha$-carbons of double links are higher, by 5 to $6 \mathrm{ppm}$ in the case of the $E$-isomer, to those observed with a $Z$ configuration of the alkenes.

In conclusion, the use of alkaline carbonates in slightly hydrated solid-liquid aprotic media allowed the synthesis of alkenes from polyfunctional aldehydes or activated ketones with high yield in a $\mathrm{Z}$ preferential stereochemistry. However, the $E$ - isomer is promoted in protic media. Wittig reactions were also performed in sodium hydroxide adsorbed on alumina.

Addition of phase transfer catalyst accelerates the Wittig reaction rate in organic media. On the contrary, in aqueous media it appears that phase-transfer agents play a harmful role.

\section{Experimental Section}

General Procedures. ${ }^{1} \mathrm{H}-\mathrm{NMR}(300 \mathrm{MHz})$ and ${ }^{13} \mathrm{C}-\mathrm{NMR}(75 \mathrm{MHz})$ spectra were recorded on a Bruker $\mathrm{AC} 300$ spectrometer in $\mathrm{CDCl}_{3}$ solvent, with tetramethylsilane as internal reference. Melting points were taken on a Reichert-Heizbank apparatus.

\section{Synthesis of the phosphonium salts}

Propyltriphenylphosphonium bromide. In a $250 \mathrm{~mL}$ two-necked flask equipped with a cooling system and magnetic stirrer, $68.1 \mathrm{~g}(260 \mathrm{mmol})$ of triphenylphosphine are introduced into $60 \mathrm{~mL}$ toluene. Then, $43.05 \mathrm{~g}(31.8 \mathrm{ml}, 350 \mathrm{mmol})$ of bromopropane are poured into the solution. The mixture is stirred during $24 \mathrm{~h}$ at $95^{\circ} \mathrm{C}$. After cooling, additional stirring is maintained for $6 \mathrm{~h}$ at room temperature. The mixture is filtered off, and the crystals are collected and washed with 80 $\mathrm{mL}$ hot toluene. The resulting product is dried at $100^{\circ} \mathrm{C}$ during $48 \mathrm{~h}$. Yield: $66 \mathrm{~g}(66 \%)$. $\mathrm{mp}=233-237^{\circ} \mathrm{C}$.

Pentyltriphenylphosphonium bromide. The protocol is identical to the preceding. Yield, 79\%; $\mathrm{mp}=165-167.5^{\circ} \mathrm{C}$.

Preparation of $\mathbf{N a O H} / \mathrm{Al}_{2} \mathrm{O}_{3} \cdot \mathrm{NaOH}(1 \mathrm{~g}, 25 \mathrm{mmol})$ is dissolved in a minimal volume of water $(2 \mathrm{~mL})$. Alumina (4g) is added. After magnetic stirring the solid is dried at $120^{\circ} \mathrm{C}$ for $12 \mathrm{~h}$. 


\section{Synthesis of olefins}

In a $25 \mathrm{~mL}$ two-necked flask equipped with a cooling system and magnetic stirrer, the phosphonium salt $(2.5 \mathrm{mmol})$, the base $(3 \mathrm{mmol})$, the solvent $(2 \mathrm{~mL})$, the aldehyde $(2 \mathrm{mmol})$ are successively placed. The mixture is stirred at the desired temperature. After filtration the solvent is removed in vacuo. The residue is washed with ether to remove most of the triphenylphosphine oxide. The alkene is isolated by column chromatography with hexane as eluent.

In reactions carried out in aqueous media, the process is the same except that after reaction and the usual work-up the residue is dried over anhydrous magnesium sulfate.

(E)- 1-Phenyl-1-butene (1). ${ }^{1} \mathrm{H}-\mathrm{NMR}\left(300 \mathrm{MHz}, \mathrm{CDCl}_{3}\right) \delta 0.96(3 \mathrm{H}, \mathrm{t}, J=7.5 \mathrm{~Hz}), 2.14-2.26$ $(2 \mathrm{H}, \mathrm{m}), 6.22(1 \mathrm{H}, \mathrm{dt}, J=15.6,6.9 \mathrm{~Hz}), 6.38(1 \mathrm{H}, \mathrm{d}, J=15.6 \mathrm{~Hz}), 7.15-7.35(3 \mathrm{H}, \mathrm{m}), 7.45(2 \mathrm{H}$, $\mathrm{d}, J=8.1 \mathrm{~Hz},) .{ }^{13} \mathrm{C}-\mathrm{NMR}\left(75 \mathrm{MHz}, \mathrm{CDCl}_{3}\right) \delta 13.77,27.01,126.46,128.14,128.50,130.76$, 131.73, 133.15.

(Z)- 1-Phenyl-1-butene (1). ${ }^{1} \mathrm{H}-\mathrm{NMR}\left(300 \mathrm{MHz}, \mathrm{CDCl}_{3}\right) \delta 0.98(3 \mathrm{H}, \mathrm{t}, J=7.5 \mathrm{~Hz}), 2.25-2.34$ $(2 \mathrm{H}, \mathrm{m}), 5.66(1 \mathrm{H}, \mathrm{dt}, J=11.7,6.9 \mathrm{~Hz}), 6.37(1 \mathrm{H}, \mathrm{d}, J=11.7 \mathrm{~Hz}), 7.14-7.36(3 \mathrm{H}, \mathrm{m}), 7.44(2 \mathrm{H}$, $\mathrm{d}, J=8.1 \mathrm{~Hz}) .{ }^{13} \mathrm{C}-\mathrm{NMR}\left(75 \mathrm{MHz}, \mathrm{CDCl}_{3}\right) \delta 13.97,22.59,126.80,128.25,128.61,130.88$, $131.70,133.25$.

(E)- 1-Phenyl-1-hexene (2). ${ }^{1} \mathrm{H}-\mathrm{NMR}\left(300 \mathrm{MHz}, \mathrm{CDCl}_{3}\right) \delta 0.94(3 \mathrm{H}, \mathrm{t}, J=7.5 \mathrm{~Hz}), 1.32-1.59$ $(4 \mathrm{H}, \mathrm{m}), 2.14-2.26(2 \mathrm{H}, \mathrm{m}), 6.23(1 \mathrm{H}, \mathrm{dt}, J=15.6,7.2 \mathrm{~Hz}), 6.39(1 \mathrm{H}, \mathrm{d}, J=15.6 \mathrm{~Hz}), 7.14-7.35$ $(3 \mathrm{H}, \mathrm{m}), 7.44(2 \mathrm{H}, \mathrm{d}, J=8.1 \mathrm{~Hz}) .{ }^{13} \mathrm{C}-\mathrm{NMR}\left(75 \mathrm{MHz}, \mathrm{CDCl}_{3}\right) \delta 13.91,23.48,31.97,32.74$, $127.66,128.66,130.75,130.88,131.74,135.12$.

(Z)- 1-Phenyl-1-hexene (2). ${ }^{1} \mathrm{H}-\mathrm{NMR}\left(300 \mathrm{MHz}, \mathrm{CDCl}_{3}\right) \delta 0.96(3 \mathrm{H}, \mathrm{t}, J=7.5 \mathrm{~Hz}), 1.32-1.60$ (4H, m), 2.15-2.28 (2H, m), $5.69(1 \mathrm{H}, \mathrm{dt}, J=6.9,11.7 \mathrm{~Hz}), 6.37(1 \mathrm{H}, \mathrm{d}, J=11.7 \mathrm{~Hz}), 7.14-7.38$ $(3 \mathrm{H}, \mathrm{m}), 7.41(2 \mathrm{H}, \mathrm{d}, J=8.1 \mathrm{~Hz}) .{ }^{13} \mathrm{C}-\mathrm{NMR}\left(75 \mathrm{MHz}, \mathrm{CDCl}_{3}\right) \delta 14.10,23.50,26.67,32.75$, $127.64,128.66,130.76,130.90,131.75,135.18$.

(E)- 1-(4-Chlorophenyl)-1-butene (3). ${ }^{1} \mathrm{H}-\mathrm{NMR}\left(300 \mathrm{MHz}, \mathrm{CDCl}_{3}\right) \delta 1.13(3 \mathrm{H}, \mathrm{t}, J=7.5 \mathrm{~Hz})$, $2.26(2 \mathrm{H}, \mathrm{qd}, J=7.5,6.6 \mathrm{~Hz}), 6.24-6.39(2 \mathrm{H}, \mathrm{m}), 7.23(2 \mathrm{H}, \mathrm{d}, J=8.1 \mathrm{~Hz}), 7.33(2 \mathrm{H}, \mathrm{d}, J=8.1$ $\mathrm{Hz}) .{ }^{13} \mathrm{C}-\mathrm{NMR}\left(75 \mathrm{MHz}, \mathrm{CDCl}_{3}\right) \delta 13.64,26.17,127.20,127.72,128.66,133.39,135.46$, 136.60.

(Z)- 1-(4-Chlorophenyl)-1-butene (3). ${ }^{1} \mathrm{H}-\mathrm{NMR}\left(300 \mathrm{MHz}, \mathrm{CDCl}_{3}\right) \delta 1.13(3 \mathrm{H}, \mathrm{t}, J=7.5 \mathrm{~Hz})$, $2.35(2 \mathrm{H}, \mathrm{qd}, J=7.5,7.2 \mathrm{~Hz}), 5.70(1 \mathrm{H}, \mathrm{dt}, J=11.7,7.2 \mathrm{~Hz}), 6.34(1 \mathrm{H}, \mathrm{d}, J=11.7 \mathrm{~Hz}), 7.22$ $(2 \mathrm{H}, \mathrm{d}, J=8.1 \mathrm{~Hz}), 7.32(2 \mathrm{H}, \mathrm{d}, J=8.1 \mathrm{~Hz}) .{ }^{13} \mathrm{C}-\mathrm{NMR}\left(75 \mathrm{MHz}, \mathrm{CDCl}_{3}\right) \delta 14.42,22.03,127.17$, $127.18,128.63,133.29,135.38,136.20$.

(E)- 1-(4-Chlorophenyl)-1-hexene (4). ${ }^{1} \mathrm{H}-\mathrm{NMR}\left(300 \mathrm{MHz}, \mathrm{CDCl}_{3}\right) \delta 0.91(3 \mathrm{H}, \mathrm{t}, J=7.2 \mathrm{~Hz})$, 1.29-1.57 (4H, m), $2.22(2 \mathrm{H}, \mathrm{dt}, J=7.26 .6 \mathrm{~Hz}), 6.22(1 \mathrm{H}, \mathrm{dt}, J=15.9,6.6 \mathrm{~Hz}), 6.36(1 \mathrm{H}, \mathrm{d}, J=$ $15.9 \mathrm{~Hz}), 7.21(2 \mathrm{H}, \mathrm{d}, J=8.4 \mathrm{~Hz}), 7.30(2 \mathrm{H}, \mathrm{d}, J=8.4 \mathrm{~Hz}) .{ }^{13} \mathrm{C}-\mathrm{NMR}\left(75 \mathrm{MHz}, \mathrm{CDCl}_{3}\right) \delta 14.05$, $22.48,32.12,32.79,127.58,128.57,130.08,132.00,133.99,136.47$.

(Z)- 1-(4-Chlorophenyl)-1-hexene (4). ${ }^{1} \mathrm{H}-\mathrm{NMR}\left(300 \mathrm{MHz}, \mathrm{CDCl}_{3}\right) \delta 0.95(3 \mathrm{H}, \mathrm{t}, J=7.2 \mathrm{~Hz})$, 1.29-1.57 (4H, m), $2.31(2 \mathrm{H}, \mathrm{dt}, J=7.2,6.6 \mathrm{~Hz}), 5.69(1 \mathrm{H}, \mathrm{dt}, J=11.7,7.2 \mathrm{~Hz}), 6.36(1 \mathrm{H}, \mathrm{d}, J=$ $11.7 \mathrm{~Hz}), 7.21(2 \mathrm{H}, \mathrm{d}, J=8.4 \mathrm{~Hz}), 7.30(2 \mathrm{H}, \mathrm{d}, J=8.4 \mathrm{~Hz}) .{ }^{13} \mathrm{C}-\mathrm{NMR}\left(75 \mathrm{MHz}, \mathrm{CDCl}_{3}\right) \delta 14.24$, $22.37,28.39,31.49,127.15,127.58,128.31,132.00,133.99,136.27$. 
(E)- 1-(4-Methylphenyl)-1-butene (5). ${ }^{1} \mathrm{H}-\mathrm{NMR}\left(300 \mathrm{MHz}, \mathrm{CDCl}_{3}\right) \delta 1.12(3 \mathrm{H}, \mathrm{t}, J=7.5 \mathrm{~Hz})$, $2.25(2 \mathrm{H}, \mathrm{qd}, J=7.5,6.6 \mathrm{~Hz}), 2.32(3 \mathrm{H}, \mathrm{s}), 6.25-6.39(2 \mathrm{H}, \mathrm{m}), 7.08(2 \mathrm{H}, \mathrm{d}, J=8.1 \mathrm{~Hz}), 7.19$ $(2 \mathrm{H}, \mathrm{d}, J=8.1 \mathrm{~Hz}) .{ }^{13} \mathrm{C}-\mathrm{NMR}\left(75 \mathrm{MHz}, \mathrm{CDCl}_{3}\right) \delta 14.00,21.20,26.12,126.80,127.72,129.23$, $130.09,132.22,136.22$.

(Z)- 1-(4-Methylphenyl)-1-butene (5). ${ }^{1} \mathrm{H}-\mathrm{NMR}\left(300 \mathrm{MHz}, \mathrm{CDCl}_{3}\right) \delta 1.12(3 \mathrm{H}, \mathrm{t}, J=7.5 \mathrm{~Hz})$, $2.34(\mathrm{qd}, 2 \mathrm{H}, J=7.5,7.2 \mathrm{~Hz}), 2.32(3 \mathrm{H}, \mathrm{s}), 5.72(2 \mathrm{H}, \mathrm{dt}, J=11.4,7.2 \mathrm{~Hz}), 6.36(1 \mathrm{H}, \mathrm{d}, J=11.4$ $\mathrm{Hz}), 7.09(2 \mathrm{H}, \mathrm{d}, J=8.1 \mathrm{~Hz}), 7.18(2 \mathrm{H}, \mathrm{d}, J=8.1 \mathrm{~Hz}) .{ }^{13} \mathrm{C}-\mathrm{NMR}\left(75 \mathrm{MHz}, \mathrm{CDCl}_{3}\right) 14.41,21.18$, $21.85,126.81,127.62,129.23,130.11,132.21,136.61$.

(E)- 1-(4-Methylphenyl)-1-hexene (6). ${ }^{1} \mathrm{H}-\mathrm{NMR}\left(300 \mathrm{MHz}, \mathrm{CDCl}_{3}\right) \delta 0.98(3 \mathrm{H}, \mathrm{t}, J=7.5 \mathrm{~Hz})$, $1.30-1.57(4 \mathrm{H}, \mathrm{m}), 2.23(2 \mathrm{H}, \mathrm{dt}, J=7.5,6.9 \mathrm{~Hz}), 2.38(3 \mathrm{H}, \mathrm{s}), 6.19(1 \mathrm{H}, \mathrm{dt}, J=15.9,6.9 \mathrm{~Hz})$, $6.41(1 \mathrm{H}, \mathrm{d}, J=15.9 \mathrm{~Hz}), 7.04(2 \mathrm{H}, \mathrm{d}, J=8.1 \mathrm{~Hz}), 7.21(2 \mathrm{H}, \mathrm{d}, J=8.1 \mathrm{~Hz}) .{ }^{13} \mathrm{C}-\mathrm{NMR}(75 \mathrm{MHz}$, $\left.\mathrm{CDCl}_{3}\right) \delta 14.18,21.09,23.20,32.21,32.68,126.32,127.21,132.09,133.15,130.10,137.27$.

(Z)- 1-(4-Methylphenyl)-1-hexene (6). ${ }^{1} \mathrm{H}-\mathrm{NMR}\left(300 \mathrm{MHz}, \mathrm{CDCl}_{3}\right) \delta 0.99(3 \mathrm{H}, \mathrm{t}, J=7.5 \mathrm{~Hz})$, $1.30-1.57(4 \mathrm{H}, \mathrm{m}), 2.29(2 \mathrm{H}, \mathrm{dt}, J=7.5,6.9 \mathrm{~Hz}), 2.38(3 \mathrm{H}, \mathrm{s}), 5.69(1 \mathrm{H}, \mathrm{dt}, J=11.1,6.9 \mathrm{~Hz})$, $6.40(1 \mathrm{H}, \mathrm{d}, J=11.1 \mathrm{~Hz}), 7.04(2 \mathrm{H}, \mathrm{d}, J=8.1 \mathrm{~Hz}), 7.21(2 \mathrm{H}, \mathrm{d}, J=8.1 \mathrm{~Hz}) \cdot{ }^{13} \mathrm{C}-\mathrm{NMR}(75 \mathrm{MHz}$, $\left.\mathrm{CDCl}_{3}\right) \delta 14.13,21.09,23.20,27.19,32.23,126.32,127.21,132.10,133.14,130.10,137.27$.

(E)- 1-(4-Methoxyphenyl)-1-butene (7). ${ }^{1} \mathrm{H}-\mathrm{NMR}\left(300 \mathrm{MHz}, \mathrm{CDCl}_{3}\right) \delta 1.14(3 \mathrm{H}, \mathrm{t}, J=7.5 \mathrm{~Hz})$, $2.24(2 \mathrm{H}, \mathrm{qd}, J=7.5,6.6 \mathrm{~Hz}), 3.80(3 \mathrm{H}, \mathrm{s}), 6.22-6.38(2 \mathrm{H}, \mathrm{m}), 7.02(2 \mathrm{H}, \mathrm{d}, J=8.1 \mathrm{~Hz}), 7.23$ $(2 \mathrm{H}, \mathrm{d}, J=8.1 \mathrm{~Hz}) .{ }^{13} \mathrm{C}-\mathrm{NMR}\left(75 \mathrm{MHz}, \mathrm{CDCl}_{3}\right) \delta 13.54,26.27,58.12,117.42,127.74,128.23$, $128.81,133.41,159.36$.

(Z)- 1-(4-Methoxyphenyl)-1-butene (7). ${ }^{1} \mathrm{H}-\mathrm{NMR}\left(300 \mathrm{MHz}, \mathrm{CDCl}_{3}\right) \delta 1.13(3 \mathrm{H}, \mathrm{t}, J=7.5$ $\mathrm{Hz}), 2.34(2 \mathrm{H}, \mathrm{qd}, J=7.5,7.2 \mathrm{~Hz}), 3.81(3 \mathrm{H}, \mathrm{s}), 5.68(1 \mathrm{H}, \mathrm{dt}, J=11.4 \mathrm{~Hz}, 7.2 \mathrm{~Hz}), 6.33(1 \mathrm{H}, \mathrm{d}, J$ $=11.4 \mathrm{~Hz}), 7.00(2 \mathrm{H}, \mathrm{d}, J=8.1 \mathrm{~Hz}), 7.22(2 \mathrm{H}, \mathrm{d}, J=8.1 \mathrm{~Hz}) .{ }^{13} \mathrm{C}-\mathrm{NMR}\left(75 \mathrm{MHz}, \mathrm{CDCl}_{3}\right) \delta$ $13.64,21.98,58.02,116.72,127.70,128.03,128.62,133.41,158.62$.

(E)- 1-(4-Methoxyphenyl)-1-hexene (8). ${ }^{1} \mathrm{H}-\mathrm{NMR}\left(300 \mathrm{MHz}, \mathrm{CDCl}_{3}\right) \delta 0.92(3 \mathrm{H}, \mathrm{t}, J=7.2 \mathrm{~Hz})$, $1.28-1.56(4 \mathrm{H}, \mathrm{m}), 2.24(2 \mathrm{H}, \mathrm{dt}, J=7.2,6.6 \mathrm{~Hz}), 3.78(3 \mathrm{H}, \mathrm{s}), 6.20(1 \mathrm{H}, \mathrm{dt}, J=15.9,6.6 \mathrm{~Hz})$, $6.39(1 \mathrm{H}, \mathrm{d}, J=15.9 \mathrm{~Hz}), 7.00(2 \mathrm{H}, \mathrm{d}, J=8.1 \mathrm{~Hz}), 7.19(2 \mathrm{H}, \mathrm{d}, J=8.1 \mathrm{~Hz}) .{ }^{13} \mathrm{C}-\mathrm{NMR}(75 \mathrm{MHz}$, $\left.\mathrm{CDCl}_{3}, 25^{\circ} \mathrm{C}\right): \delta 14.10,23.21,32.06,32.69,56.02,117.41,127.52,128.28,128.32,132.82$, 161.19.

(Z)- 1-(4-Methoxyphenyl)-1-hexene (8). ${ }^{1} \mathrm{H}-\mathrm{NMR}\left(300 \mathrm{MHz}, \mathrm{CDCl}_{3}\right) \delta 0.96(3 \mathrm{H}, \mathrm{t}, J=7.2$ $\mathrm{Hz}), 1.28-1.56(4 \mathrm{H}, \mathrm{m}), 2.31(2 \mathrm{H}, \mathrm{dt}, J=7.2,6.6 \mathrm{~Hz}), 3.78(3 \mathrm{H}, \mathrm{s}), 5.63(1 \mathrm{H}, \mathrm{dt}, J=11.4,7.2$ $\mathrm{Hz}), 6.38(1 \mathrm{H}, \mathrm{d}, J=11.4 \mathrm{~Hz}), 6.98(2 \mathrm{H}, \mathrm{d}, J=8.1 \mathrm{~Hz}), 7.21(2 \mathrm{H}, \mathrm{d}, J=8.1 \mathrm{~Hz}) \cdot{ }^{13} \mathrm{C}-\mathrm{NMR}(75$ $\left.\mathrm{MHz}, \mathrm{CDCl}_{3}\right) \delta 14.08,23.18,26.81,32.06,56.32,117.11,127.54,128.18,128.32,132.80$, 160.19 .

(E)- 1-Furanyl-1-butene (9). ${ }^{1} \mathrm{H}-\mathrm{NMR}\left(300 \mathrm{MHz}, \mathrm{CDCl}_{3}\right) \delta 1.05(3 \mathrm{H}, \mathrm{t}, J=7.2 \mathrm{~Hz}), 2.31(2 \mathrm{H}$, $\mathrm{dq}, J=7.2,6.9 \mathrm{~Hz}), 6.13-6.44(4 \mathrm{H}, \mathrm{m}), 7.43(1 \mathrm{H}, \mathrm{d}, J=1.8 \mathrm{~Hz}) .{ }^{13} \mathrm{C}-\mathrm{NMR}\left(75 \mathrm{MHz}, \mathrm{CDCl}_{3}\right) \delta$ 13.68, 29.02, 111.09, 117.40, 128.49, 132.20, 133.16, 141.20.

(Z)- 1-Furanyl-1-butene (9). ${ }^{1} \mathrm{H}-\mathrm{NMR}\left(300 \mathrm{MHz}, \mathrm{CDCl}_{3}\right) \delta 1.11(3 \mathrm{H}, \mathrm{t}, J=7.2 \mathrm{~Hz}), 2.26-2.39$ $(2 \mathrm{H}, \mathrm{m}), 5.55(\mathrm{dt}, 1 \mathrm{H}, J=12,7.2 \mathrm{~Hz}), 6.20-6.38(3 \mathrm{H}, \mathrm{m}), 7.43(1 \mathrm{H}, \mathrm{d}, J=1.8 \mathrm{~Hz})$.

${ }^{13} \mathrm{C}$ NMR $\left(75 \mathrm{MHz}, \mathrm{CDCl}_{3}\right) \delta 13.98,22.47,111.10,117.40,128.65,132.07,133.26,142.10$. 
(E)- 1-Furanyl-1-hexene (10). ${ }^{1} \mathrm{H}-\mathrm{NMR}\left(300 \mathrm{MHz}, \mathrm{CDCl}_{3}\right) \delta 0.95$ (3H, t, $\left.J=7.2 \mathrm{~Hz}\right), 1.32-1.55$ $(4 \mathrm{H}, \mathrm{m}), 2.20-2.34(2 \mathrm{H}, \mathrm{m}), 6.17-6.39(4 \mathrm{H}, \mathrm{m}), 7.41(1 \mathrm{H}, \mathrm{d}, J=1.8 \mathrm{~Hz}) .{ }^{13} \mathrm{C}$ NMR $(75 \mathrm{MHz}$, $\left.\mathrm{CDCl}_{3}\right) \delta 14.02,23.48,29.98,31.34,111.93,115.41,127.92,132.17,135.26,144.47$.

(Z)- 1-Furanyl-1-hexene (10). ${ }^{1} \mathrm{H}-\mathrm{NMR}\left(300 \mathrm{MHz}, \mathrm{CDCl}_{3}\right) \delta 1.02(3 \mathrm{H}, \mathrm{t}, J=7.2 \mathrm{~Hz}), 1.29-1.53$ $(4 \mathrm{H}, \mathrm{m}), 2.18-2.34(2 \mathrm{H}, \mathrm{m}), 5.65(1 \mathrm{H}, \mathrm{dt}, J=7.2,12 \mathrm{~Hz}), 6.25-6.46(3 \mathrm{H}, \mathrm{m}), 7.43(1 \mathrm{H}, \mathrm{d}, J=1.8$ $\mathrm{Hz}) .{ }^{13} \mathrm{C}$ NMR $\left(75 \mathrm{MHz}, \mathrm{CDCl}_{3}\right) \delta 14.22,23.38,24.02,31.41,111.96,115.41,127.91,132.17$, $135.28,144.46$.

(E)- 1-(5-Methylfuranyl)-1-butene (11). ${ }^{1} \mathrm{H}-\mathrm{NMR}\left(300 \mathrm{MHz}, \mathrm{CDCl}_{3}\right) \delta 1.06(3 \mathrm{H}, \mathrm{t}, J=7.2 \mathrm{~Hz})$, 2.19-2.31 (5H, m), 6.12-6.43 (4H, m). ${ }^{13} \mathrm{C}-\mathrm{NMR}\left(75 \mathrm{MHz}, \mathrm{CDCl}_{3}\right) \delta 13.86,15.10,26.02$, 108.76, 113.09, 127.86, 132.82, 148.50, 149.25.

(Z)- 1-(5-Methylfuranyl)-1-butene (11). ${ }^{1} \mathrm{H}-\mathrm{NMR}\left(300 \mathrm{MHz}, \mathrm{CDCl}_{3}\right) \delta 1.04(3 \mathrm{H}, \mathrm{t}, J=7.2 \mathrm{~Hz})$, 2.12-2.30 (5H, m), $5.66(1 \mathrm{H}, \mathrm{dt}, J=7.2,12 \mathrm{~Hz}), 5.96-6.42(3 \mathrm{H}, \mathrm{m}) .{ }^{13} \mathrm{C}-\mathrm{NMR}\left(75 \mathrm{MHz}, \mathrm{CDCl}_{3}\right)$ $\delta 13.54,15.10,20.10,108.52,113.02,127.62,132.24,148.50,149.20$.

(E)- 1-(5-Methylfuranyl)-1-hexene (12). ${ }^{1} \mathrm{H}-\mathrm{NMR}\left(300 \mathrm{MHz}, \mathrm{CDCl}_{3}\right) \delta 1.02(3 \mathrm{H}, \mathrm{t}, J=7.2$ $\mathrm{Hz}), 1.33-2.20(9 \mathrm{H}, \mathrm{m}), 5.98-6.42(4 \mathrm{H}, \mathrm{m}) .{ }^{13} \mathrm{C}-\mathrm{NMR}\left(75 \mathrm{MHz}, \mathrm{CDCl}_{3}\right) \delta 14.15,15.12,22.97$, $30.12,32.10,108.60,113.00,127.46,134.60,149.52,150.62$.

(Z)- 1-(5-Methylfuranyl)-1-hexene (12). ${ }^{13} \mathrm{C}-\mathrm{NMR}\left(75 \mathrm{MHz}, \mathrm{CDCl}_{3}\right) \delta 14.12,15.10,23.15$, 24.25, 31.96, 108.54, 113.14, 127.32, 135.20, 149.02, 150.50 .

(E)- 2-Pentene (13). ${ }^{1} \mathrm{H}-\mathrm{NMR}\left(300 \mathrm{MHz}, \mathrm{CDCl}_{3}\right) \delta 1.16(3 \mathrm{H}, \mathrm{t}, J=7.5 \mathrm{~Hz}), 1.76(3 \mathrm{H}, \mathrm{d}, J=7.2$ $\mathrm{Hz}), 2.11(2 \mathrm{H}, \mathrm{dq}, J=7.5,6.9 \mathrm{~Hz}), 5.47-5.54(2 \mathrm{H}, \mathrm{m}) .{ }^{13} \mathrm{C}-\mathrm{NMR}\left(75 \mathrm{MHz}, \mathrm{CDCl}_{3}\right) \delta 14.02$, $17.60,26.71,133.30,123.70$.

(Z)- 2-Pentene (13). ${ }^{1} \mathrm{H}-\mathrm{NMR}\left(300 \mathrm{MHz}, \mathrm{CDCl}_{3}\right) \delta 1.16(3 \mathrm{H}, \mathrm{t}, J=7.5 \mathrm{~Hz}), 1.76(3 \mathrm{H}, \mathrm{d}, J=7.2$ $\mathrm{Hz}), 2.11(2 \mathrm{H}, \mathrm{dq}, J=7.5,6.9 \mathrm{~Hz}), 5.41-5.48(2 \mathrm{H}, \mathrm{m}) .{ }^{13} \mathrm{C}-\mathrm{NMR}\left(75 \mathrm{MHz}, \mathrm{CDCl}_{3}\right) \delta 12.38$, $14.00,20.51,123.20,132.70$.

(E)- 2-Heptene (14). ${ }^{1} \mathrm{H}-\mathrm{NMR}\left(300 \mathrm{MHz}, \mathrm{CDCl}_{3}\right) \delta 0.98(3 \mathrm{H}, \mathrm{t}, J=7.5 \mathrm{~Hz}), 1.30-1.50(4 \mathrm{H}, \mathrm{m})$, $1.79(3 \mathrm{H}, \mathrm{s}), 2.13(2 \mathrm{H}, \mathrm{dt}, J=7.5,6.9 \mathrm{~Hz}), 5.48-5.54(2 \mathrm{H}, \mathrm{m}) .{ }^{13} \mathrm{C}-\mathrm{NMR}\left(75 \mathrm{MHz}, \mathrm{CDCl}_{3}\right) \delta$ $14.08,17.70,23.81,33.20,34.70,126.20,133.13$.

(Z)- 2-Heptene (14). ${ }^{13} \mathrm{C}-\mathrm{NMR}\left(75 \mathrm{MHz}, \mathrm{CDCl}_{3}\right) \delta$ 13.92, 13.60, 22.80, 29.42, 33.00, 125.00, 136.30 .

(E)- 3-Hexene (15). ${ }^{1} \mathrm{H}-\mathrm{NMR}\left(300 \mathrm{MHz}, \mathrm{CDCl}_{3}\right) \delta 1.14(6 \mathrm{H}, \mathrm{t}, J=7.5 \mathrm{~Hz}), 2.13$ (4H, dq, $J=$ 7.5, 6.9 Hz), 5.48-5.55 (2H, m). ${ }^{13} \mathrm{C}-\mathrm{NMR}\left(75 \mathrm{MHz}, \mathrm{CDCl}_{3}\right) \delta 14.00,26.50,131.30$.

(Z)- 3-Hexene (15). ${ }^{13} \mathrm{C}-\mathrm{NMR}\left(75 \mathrm{MHz}, \mathrm{CDCl}_{3}\right)$ 14.00, 21.20, 131.20.

(E)- 3-Octene (16). ${ }^{1} \mathrm{H}-\mathrm{NMR}\left(300 \mathrm{MHz}, \mathrm{CDCl}_{3}\right) \delta 0.92(3 \mathrm{H}, \mathrm{t}, J=7.2 \mathrm{~Hz}), 1.28-1.56(4 \mathrm{H}, \mathrm{m})$, 2.10-2.31 (4H, m), 5.49-5.57 (2H, m). ${ }^{13} \mathrm{C}$ NMR (75 MHz, $\left.\mathrm{CDCl}_{3}\right) \delta 14.00,14.15,22.52,26.40$, $32.10,32.80,128.84,133.44$.

(Z)- 3-Octene (16). ${ }^{13} \mathrm{C}-\mathrm{NMR}\left(75 \mathrm{MHz}, \mathrm{CDCl}_{3}\right) \delta 14.05,14.15,21.08,27.10,32.05,128.84$, 133.24 .

(E)- 3-Heptene (17). ${ }^{1} \mathrm{H}-\mathrm{NMR}\left(300 \mathrm{MHz}, \mathrm{CDCl}_{3}\right) \delta 0.94-1.10$ (6H, m), 1.27-1.51 (2H, m), 2.09$2.32(4 \mathrm{H}, \mathrm{m}), 5.47-5.54(2 \mathrm{H}, \mathrm{m}) .{ }^{13} \mathrm{C}-\mathrm{NMR}\left(75 \mathrm{MHz}, \mathrm{CDCl}_{3}\right) \delta 14.00,14.20,23.80,27.05$, $32.00,33.30,127.90,132.74$. 
(Z)- 3-Heptene (17). ${ }^{13} \mathrm{C}-\mathrm{NMR}\left(75 \mathrm{MHz}, \mathrm{CDCl}_{3}\right) \delta$ 14.06, 14.15, 21.10, 23.12, 28.50, 128.52, 130.80 .

(E)- 4-Nonene (18). ${ }^{1} \mathrm{H}-\mathrm{NMR}\left(300 \mathrm{MHz}, \mathrm{CDCl}_{3}\right) \delta$ 0.92-1.11 (6H, m), 1.22-1.49 (6H, m), 2.12$2.29(4 \mathrm{H}, \mathrm{m}), 5.51-5.59(2 \mathrm{H}, \mathrm{m}) .{ }^{13} \mathrm{C}-\mathrm{NMR}\left(75 \mathrm{MHz}, \mathrm{CDCl}_{3}\right) \delta 14.12,14.18,22.92,23.15$, $32.02,33.30,36.50,128.90,132.10$.

(Z)- 4-Nonene (18). ${ }^{13} \mathrm{C}-\mathrm{NMR}\left(75 \mathrm{MHz}, \mathrm{CDCl}_{3}\right) \delta$ 14.08, 14.20, 23.04, 23.18, 27.02, 29.58, $33.22,129.12,132.15$.

(E) 3-Undecene (19). ${ }^{1} \mathrm{H}-\mathrm{NMR}\left(300 \mathrm{MHz}, \mathrm{CDCl}_{3}\right) \delta$ 0.96-1.05 (6H, m), 1.29-1.59 (8H, m), 1.96-2.13 (4H, m), 5.47-5.54 (2H, m). ${ }^{13} \mathrm{C}-\mathrm{NMR}\left(75 \mathrm{MHz}, \mathrm{CDCl}_{3}\right) \delta 14.00,14.20,23.22,26.80$, $29.85,30.25,30.45,32.62,127.95,133.35$.

(Z)- 3-Undecene (19). ${ }^{13} \mathrm{C}-\mathrm{NMR}\left(75 \mathrm{MHz}, \mathrm{CDCl}_{3}\right) \delta 14.02,14.20,20.85,23.20,27.80,29.82$, 30.22, 30.50, 32.57, 128.00, 133.34 .

(E)- 3-Tridecene (20). ${ }^{1} \mathrm{H}-\mathrm{NMR}\left(300 \mathrm{MHz}, \mathrm{CDCl}_{3}\right) \delta$ 0.94-1.12 (6H, m), 1.23-1.67 (12H, m), 1.93-2.14 (4H, m), 5.47-5.54 (2H, m). ${ }^{13} \mathrm{C}-\mathrm{NMR}\left(75 \mathrm{MHz}, \mathrm{CDCl}_{3}\right) \delta 14.01,14.13,23.18,23.38$, $30.10,30.50,30.54,32.28,32.45,33.42,33.92$, 128.35, 132.62 .

(Z)- 3-Tridecene (20). ${ }^{13} \mathrm{C}-\mathrm{NMR}\left(75 \mathrm{MHz}, \mathrm{CDCl}_{3}\right) \delta 14.00,14.15,23.20,23.42,26.17,29.95$, $30.09,30.52,30.62,32.44,33.23,129.20,132.12$.

(E)- 3-Dodecene (21). ${ }^{13} \mathrm{C}-\mathrm{NMR}\left(75 \mathrm{MHz}, \mathrm{CDCl}_{3}\right) \delta 14.02,14.16,23.52,26.20,29.64,30.20$, $30.35,30.42,32.52,33.38,128.86,132.54$.

(Z)- 3-Dodecene (21). ${ }^{13} \mathrm{C}-\mathrm{NMR}\left(75 \mathrm{MHz}, \mathrm{CDCl}_{3}\right) \delta 14.04,14.16,20.18,23.48,28.60,29.82$, $30.20,30.54,30.60,32.56,129.00,132.80$.

(E)- 5-Tetradecene (22). ${ }^{1} \mathrm{H}-\mathrm{NMR}\left(300 \mathrm{MHz}, \mathrm{CDCl}_{3}\right) \delta$ 0.93-1.02 (6H, m), 1.22-1.67 (16H, m), 1.94-2.13 (4H, m), 5.46-5.58 (2H, m). ${ }^{13} \mathrm{C}-\mathrm{NMR}\left(75 \mathrm{MHz}, \mathrm{CDCl}_{3}\right) \delta 14.02,14.16,23.00,23.42$, $30.35,30.48,30.52,32.58,33.05,33.41,131.68,131.85$.

\section{References}

1. Maryanoff, B. E.; Reitz, A. B. Chem. Rev. 1989, 89, 863.

2. Russell, M. G.; Warren, S. J. Chem. Soc., Perkin Trans. 2000, 505.

3. Nicolaou, K. C.; Härter, M. W.; Gunzer, J. L.; Nadin, A. Liebigs Ann., Recueil 1997, 1283.

4. Maeycker, A. Organic Reactions, Wiley: New York, 1965, Vol. 14 p.270.

5. Kiddle, J. J. Tetrahedron Lett. 2000, 41, 1339.

6. Schlosser, M. Topics Stereochem. 1970, 5, 1.

7. Vedejs, E.; Snoble, K. A. J. J. Am. Chem. Soc. 1973, 95, 5778.

8. Wang, Q.; Elkhoury, M.; Schlosser, M. Chem. Eur. J. 2000, 6, 420.

9. Kojima, S.; Takagi, R.; Akiba, K. J. Am. Chem. Soc. 1997, 119, 5970.

10. Tsukamoto, M.; Schlosser, M. Synlett. 1990, 605.

11. Vedajs, E.; Marth, C. F.; Ruggeri, R. J. Am. Chem. Soc. 1988, 110, 3940.

12. Vedejs, E.; Marth, C. F. J. Am. Chem. Soc. 1988, 110, 3948. 
13. Yamataka, H.; Nagareda, K.; Ando, K.; Hanafusa, T. J. Org. Chem. 1992, 57, 2865.

14. Wang, Z.; Zhang, G.; Guzei, I.; Verkade, J. G. J. Org. Chem. 2001, 66, 3521.

15. Wu, J.; Wu, H.; Wei, S.; Wei, M. D. Tetrahedron Lett. 2004, 45, 4401.

16. Ward J. W. J.; McEwen W. E., J. Org. Chem. 1990, 55, 493.

17. Vedejs, E.; Peterson, M. J. Top Stereochem. 1994, $21,1$.

18. Aksnes, G.; Berg, T. J.; Gramstad, T. Phosphorus, Sulfur, Silicon, Relat. Elem. 1995, 106, 79.

19. Le Bigot, Y.; Elgharbi, R.; Delmas, M.; Gaset, A. Tetrahedron 1986, 42, 3813.

20. Oh, J. S.; Park, D.Y., Song, B. S.; Bae, J. G.; Yoon, S. W.; Kim, Y. G. Tetrahedron Lett. 2002, 43, 7209.

21. Oh, J. S.; Kim, B. H.; Kim, Y. G. Tetrahedron Lett. 2004, 45, 3925.

22. Moussaoui, Y.; Ben Salem, R. J. Soc. Chim. Tunisie 2003, 5, 255.

23. Weber, W. P.; Gokel, G. W. J. Chem. Ed. 1978, 55, 429.

24. Texier-Boullet, F.; Foucaud, A. Tetrahedron Lett. 1980, 2161.

25. Mikolajczyk, M.; Grzejszczak, S.; Midura, W.; Zatorski, A. Synthesis 1976, 396.

26. Weber, W. P.; Gokel, G. W. Phase Transfer Catalysis in Organic Synthesis, Springer Verlag: Berlin, 1977.

27. Le Bigot, Y.; Delmas, M.; Gaset, A. Synth. Comm. 1983, 13, 177.

28. Mouloungui, Z.; Delmas, M.; Gaset A. Synth. Comm. 1985, 15, 491.

29. Le Bigot, Y.; Hajjaji, N.; Rico, I.; Lattes, A.; Delmas, M.; Gaset, A. Synth. Comm. 1985, 15, 495.

30. Imashiro, R.; Sakurai, O.; Yamashita, T.; Horikawa, H. Tetrahedron 1998, 54, 10657.

31. Le Bigot, Y.; Delmas, M.; Gaset, A. Synth. Comm. 1982, 12, 107.

32. Maryanoff, B. E.; Reitz, A. B.; Mutter, M. S.; Inners, R. R.; Almond, H. R.; Whittle R. R.; Olofson, R. A. J. Am. Chem. Soc. 1986, 108, 7664.

33. Appel, M., Blanrock, S., Berger, S. Eur. J. Org. Chem. 2002, 1143. 